\title{
Aspectos da composição e diversidade do componente arbóreo das florestas da Reserva Florestal do Morro Grande, Cotia, SP
}

\author{
Eduardo Luís Martins Catharino ${ }^{1}$, Luís Carlos Bernacci², Geraldo Antonio Daher Correa Franco ${ }^{3}$, Giselda Durigan ${ }^{4}$ \\ \& Jean Paul Metzger ${ }^{5}$
}

Biota Neotropica v6 (n2)-http://www.biotaneotropica.org.br/v6n2/pt/abstract?article+bn00306022006

Recebido em 23/5/2005

Versão reformulada recebida em 12/10/2005.

Publicado em 01/05/2006

\author{
${ }^{1}$ Instituto de Botânica de São Paulo, Caixa Postal 4005, 01061-970 São Paulo, SP \\ (autor para correspondência: mcatarin@uol.com.br) \\ ${ }^{2}$ Instituto Agronômico de Campinas (IAC), Av. Barão de Itapura, 1481, Caixa Postal 28, 13001-970 Campinas, SP \\ ${ }^{3}$ Instituto Florestal, Rua do Horto, 931, 02377-000 São Paulo, SP \\ ${ }^{4}$ Instituto Florestal, Estrada Assis-Lutécia km 09, Caixa Postal 104, 19800-000 Assis, SP \\ ${ }^{5}$ Departamento de Ecologia, Instituto de Biociências, Universidade de São Paulo, Rua do Matão, 321, travessa 14, \\ 05508-900 São Paulo, SP
}

\begin{abstract}
Catharino, E.L.M., Bernacci, L.C., Franco, G.A.D.C., Durigan, G. and Metzger, J.P. Tree species composition and diversity of the Morro Grande Forest Reserve, Cotia, SP, Brazil. Biota Neotrop. May/Aug 2006 vol. 6 no. 2, http:// www.biotaneotropica.org.br/v6n2/pt/abstract?article+bn00306022006. ISSN 1676-0603
\end{abstract}

The main objective of this study was to characterize the tree arboreal species composition and to compare secondary and mature forests of the Morro Grande Forest Reserve (Cotia, metropolitan region of São Paulo, Brazil). Based on this evaluation, we discuss the forest type classification and the conservation value of this Reserve. We used the point centered quarter method, sampling 2,400 trees in six different sites, three with secondary forests and three other ones with a predominance of mature forests. In each site, four blocks of 25 points were assessed, totalizing 100 points or 400 individuals. The blocks were $200 \mathrm{~m}$ apart from each other. Data were analyzed through cluster and Detrended Correspondence Analysis (DCA). Results showed differences among sites, essentially differentiating the secondary and mature sites. DCA and cluster analyses were particularly useful to detect characteristic species for these two main successsional stages. Among the 260 species observed, only 12 were sampled in the six sites. Richness and diversity were surprisingly high when compared with previous studies in the study region. The Shannon diversity values were among the highest in the state of São Paulo, with 4.75 nats/tree for the whole sampling, 4.25 nats/tree for the three secondary sites, and 4.54 nats/tree for the three mature sites. The studied forest may be essentially classified as “Dense Mountain Rain Forest” presenting species from the Araucaria mixed forest, and also from the semi-deciduous forest and Cerrado (woody savanna) region. Those results seem to confirm the hypothesis of a "high montane refuge" in drier climatic conditions in the past. The high richness and mixed composition of different floras highlighted the importance to preserve the Morro Grande forest.

Key words: Dense Mountain Rain Forest, tree species composition, richness and diversity, secondary and mature forests, São Paulo Atlantic Plateau

http://www.biotaneotropica.org.br 


\section{Resumo}

Catharino, E.L.M., Bernacci, L.C., Franco, G.A.D.C., Durigan, G. and Metzger, J.P. - Aspectos da composição e diversidade do componente arbóreo das florestas da Reserva Florestal do Morro Grande, Cotia, SP. Biota Neotrop. May/Aug 2006 vol. 6 no. 2, http://www.biotaneotropica.org.br/v6n2/pt/abstract?article+bn00306022006. ISSN 1676-0603.

Este trabalho procurou caracterizar a composição florística arbórea e comparar florestas secundárias e maduras da Reserva Florestal do Morro Grande (RFMG), em Cotia, região metropolitana de São Paulo. Discute-se, também, a classificação utilizada para denominar esta cobertura florestal e a importância da RFMG para conservação. Utilizou-se o método de pontos quadrantes, amostrando-se 2400 árvores em seis áreas, três localizadas em regiões com florestas secundárias e três com predomínio de florestas mais conservadas ou maduras. Em cada local, levantaram-se 400 indivíduos arbóreos em 100 pontos-quadrantes, divididos em blocos de 25 pontos distantes $200 \mathrm{~m}$ uns dos outros. Os dados por áreas e blocos foram analisados através de agrupamento e ordenamento (UPGMA e DCA). Das 260 espécies arbóreas encontradas, apenas 12 foram amostradas nas seis áreas. A riqueza encontrada foi surpreendentemente alta quando comparada a outros levantamentos feitos na região. Os índices de diversidade de Shannon (H') situam-se entre os maiores para as florestas paulistas: 4,75 nats/ indivíduo para a amostragem total; 4,25 para as três áreas secundárias; e 4,54 para as três áreas maduras. A amostra estratificada permitiu verificar a variação interna da floresta, revelando diferenças em riqueza e abundância entre os seis locais e os blocos de amostragem, em particular diferenciando as áreas secundárias e maduras. A DCA mostrou-se útil na detecção de espécies características dentro do gradiente sucessional. A floresta em geral pode ser classificada como "floresta ombrófila densa montana", com presença de espécies de florestas mistas, estacionais semideciduais e cerradão, o que parece confirmar a existência, no local, de um antigo "refúgio alto-montano" sob condições de climas mais secos no passado, assim como o caráter ecotonal das florestas da região. A riqueza e mistura de elementos de várias floras denotam a importância da conservação da Reserva Florestal do Morro Grande.

Palavras-chave: Floresta Ombrófila Densa Montana, composição, riqueza e diversidade florística, florestas secundárias e maduras, Planalto Atlântico paulista 


\section{Introdução}

A classificação das florestas do Planalto Atlântico da grande São Paulo sempre se mostrou controversa (Ivanaukas 1997). De fato, alguns autores têm considerado as florestas regionais como um tipo de floresta estacional (Baitello \& Aguiar 1982) ou similar à de outras regiões de altitude do Planalto Atlântico (Rodrigues 1986, Silva 1989, Grombone-Guaratini et al. 1990, Cardoso Leite 1995) e do interior paulista (Pagano 1985, Catharino 1989, Martins 1991, Gandolfi 2000). Assim, Gandolfi et. al. (1995) e Pivello \& Peccinini (2002) consideraram as florestas paulistanas como "floresta mesófila semidecídua” ou "floresta estacional semidecidual”, enquanto Roizman (1993), Aragaki (1997) e Gomes (1998) consideram mais adequado enquadrá-las como "floresta ombrófila densa", destacando sua condição de “transição”. A presença regional de espécies arbóreas, arbustivas e herbáceas típicas dos cerrados e das florestas estacionais e elementos associados a florestas mistas e da flora campestre do sul do Brasil, em maior ou menor proporção, é bastante relatada (Joly 1950, Hueck 1956, Garcia 1995, Catharino 1996, Aragaki 1997).

A região metropolitana de São Paulo teve recobrimento original por "florestas subtropicais de planalto, com presença de araucária dispersas”, e pequenos encraves de campos e cerrados (Hueck 1956). As florestas desta região foram denominadas por Eiten (1970) de "floresta perenifólia ou sempre-verde de planalto”, tidas como transição das florestas da encosta para o interior, e para as regiões mais frias, podendo ser arbitrariamente estabelecida uma divisão de um grupo a sudeste e próximo do mar e ao interior ou nordeste. Salis et al. (1995) também destacou a existência destes dois tipos de “florestas de planalto" no Estado. Aragaki \& Mantovani (1998) mostram que o Planalto Paulistano encontra-se em faixa de "transição florística" com a co-existência de espécies das florestas ombrófila densa, estacional semidecidual e do cerradão, devido a ligações pretéritas destas floras ou a existência de "corredores de migração”. Estes autores consideram, assim, as florestas do planalto paulistano como ecotonais, diferenciadas tanto das típicas estacionais semideciduais do interior e da floresta ombrófila densa da encosta, embora mais próximas destas últimas, ponderando que o clima no Planalto Paulistano é de transição entre temperado e tropical.

Apesar da intensa fragmentação e alteração antrópica das florestas no entorno da cidade de São Paulo, o que provavelmente tem gerado interpretações duvidosas sobre sua correta denominação, ainda restam alguns remanescentes representativos, como o caso da Reserva Florestal do Morro Grande (RFMG). Trata-se de um dos maciços florestais mais extensos e preservados do Planalto Atlântico do entorno da metrópole paulistana, sendo um bom testemunho da flora regional. A RFMG possui predominantemente florestas regeneradas, notadamente após a proteção das cabeceiras do rio Cotia, em um grande mosaico sucessional com pequenos trechos de florestas "maduras”, ou sem corte raso aparente, notadamente ao sul.

O objetivo principal deste trabalho foi de caracterizar a flora arbórea predominante da RFMG e, através deste conhecimento, subsidiar ações de manejo e conservação. Mais especificamente, este trabalho procura analisar as variações internas da riqueza e diversidade florística ao analisar os dois principais tipos florestais que ocorrem na RFMG: florestas maduras, onde houve apenas extração seletiva de madeira; e florestas em estádio intermediário/ avançado de sucessão, que sofreram corte raso há cerca de 80-90 anos atrás. Procurou-se, ainda, identificar espécies arbóreas características de florestas secundárias e de florestas maduras e discutir, com base na amostra florística, se as florestas regionais são típicas ombrófilas ou se elas possuem carácter transicional.

\section{Métodos}

\section{Localização e caracterização geral}

A Reserva Florestal do Morro Grande está situada no alto da Serra de Paranapiacaba, entre 860 a 1075 m de altitude, sobre o Planalto de Ibiúna, nos limites da Morraria do Embu e Bacia de São Paulo, 34 km a leste do centro da cidade de São Paulo. Encontra-se em zona de transição entre as bacias hidrográficas litorâneas e interiores da costa sudeste do Brasil. O clima predominante pode ser classificado como Cfb (Köppen 1948), descrito como temperado de inverno menos seco, com regime de chuvas de verão, temperatura média do mês mais quente abaixo de $22^{\circ} \mathrm{C}$ e do mês mais frio abaixo de $18^{\circ} \mathrm{C}$, tipicamente serrano no estado. No entanto, como em outros aspectos, regionalmente ocorre uma faixa transicional para climas de invernos mais secos $(C w)$, ou de verões mais quentes $(C f a)$, ou quentes e úmidos sem estação seca $(A f)$, na estreita faixa entre o Oceano Atlântico e a Depressão Periférica Paulista. Assim, a nordeste da Reserva, na região central da bacia de São Paulo, o clima é considerado $C w b$, com seca pouco mais pronunciada no inverno. Em direção ao interior ou noroestenorte, nas regiões montanas, predomina o clima $C f a$, com verões pouco mais quentes. Em direção à calha do Paraná, o clima é Cwa, mais quente e mais sazonal. Em altitudes mais baixas, já na fachada da escarpa da Serra do Mar voltada ao Atlântico, também poucos quilômetros a sul-sudeste do Morro Grande, o clima é do tipo Af, mais quente, mais chuvoso e sem estação seca pronunciada (Setzer 1946, Eiten 1970, Gandolfi 1991, Aragaki \& Mantovani 1998). Tarifa \& Armani (2001) reforçam a idéia de transição climática entre os climas tropicais úmidos de altitude, com período seco definido, e aqueles subtropicais, permanentemente úmidos, do Brasil Meridional. Pela sua classificação, a Reserva do Morro Grande poderia se enquadrar na transição da unidade 
“clima tropical úmido de altitude do Planalto Paulistano” à unidade referida como "clima tropical sub-oceânico superúmido do reverso do Planalto Atlântico”.

Metzger et al. (2006) fornecem maior detalhamento sobre as características climáticas e geomorfológicas, bem como sobre o embasamento geológico, pedologia, hidrografia, uso e cobertura da Reserva Florestal do Morro Grande.

\section{Escolha das seis áreas de amostragem}

Os levantamentos foram planejados para amostrar as duas fisionomias florestais predominantes na RFMG: o estádio secundário médio/avançado (6950 ha) e a floresta madura (2451 ha) (Metzger et al. 2006). Estes estádios foram inicialmente reconhecidos pela fisionomia, distribuição de classes de diâmetro, abundância de grandes indivíduos e espécies tardias, presença de epífitas, bromélias, bambus e clareiras, entre outros. Posteriormente, elaborou-se um mapeamento da distribuição espacial destas fisionomias principais, apresentadas em Metzger et al. (op.cit.).

Foram demarcadas três áreas em regiões com florestas secundárias, em estádio médio/avançado, e três áreas em regiões com florestas de pouca perturbação, denominadas áreas maduras ou predominantemente maduras (ver Figura 13 em Metzger et al. 2006). Foi obedecido um espaçamento mínimo de 2,4 km de distância entre áreas, de forma a garantir a independência dos dados biológicos.

As três áreas “secundárias”, $A, B$ e $C$, com pelo menos cerca de 80 anos de regeneração após corte raso, situam-se ao norte da Reserva, ocupadas, antes da construção da Barragem “Cachoeira da Graça” (1914-1917), por pastos ou roças de sítios e pequenas fazendas. As três áreas de florestas, “predominantemente maduras”, estão ao sul, nas proximidades das cabeceiras do rio Cotia, nos divisores com o rio Sorocamirim (médio-Tietê) e o rio Laranjeiras (Ribeira de Iguape), possuindo trechos que aparentemente nunca sofreram o corte raso, entre outros pouco perturbados e com regeneração avançada. Nestas cabeceiras, foram escolhidas outras três áreas de amostragem, Quilombo (Q), Grilos $(G)$ e Torres (T), ao longo do perímetro oeste-sul da RFMG.

\section{Coleta de dados}

Considerando a heterogeneidade das florestas regionais, amostrou-se 1200 árvores em três áreas secundárias e 1200 em três áreas predominantemente maduras, número equivalente ou superior ao utilizado em outros levantamentos no Planalto Atlântico.

A amostragem foi efetuada pelo método de quadrantes (Cottam \& Curtis 1956), de forma sistemática, independentemente da situação topográfica, em quatro conjuntos amostrais (blocos) distantes $200 \mathrm{~m}$ uns dos outros, em cada área. Para tal, foram estabelecidas duas transecções paralelas de pelo menos $460 \mathrm{~m}$, onde se amostraram os $130 \mathrm{~m}$ iniciais e finais, iniciando-se no mínimo a $10 \mathrm{~m}$ de bordas ou caminhos. Cada bloco amostral foi composto de 25 pontos-quadrante em duas fileiras, sendo 13 pontos ao longo da transecção e 12 em fileira paralela. Obedeceu-se um intervalo de $10 \mathrm{~m}$ entre pontos, acrescidos em um metro ou mais sucessivamente, em caso de sobreposição com a amostragem anterior ou lateral. Foram amostrados, em cada bloco, 100 indivíduos com Diâmetro à Altura do Peito $(\mathrm{DAP}=1,30 \mathrm{~m})$ e" $5 \mathrm{~cm}$, totalizando 400 indivíduos por área. Assim, foram amostradas 2400 árvores em 24 blocos, aplicados em conjuntos de quatro blocos amostrais em seis áreas ( $A, B, C$, Quilombo, Grilos e Torres).

O material botânico para identificação foi coletado com tesoura de alta-poda, atiradeira de punho, escalada ou tiros com cartucheira 28, tendo processamento usual (prensagem, secagem, etiquetagem). Foram priorizadas as coletas de todos os materiais com possibilidade de erros de identificação em campo, notadamente Myrtaceae, Lauraceae e Rubiaceae. Posteriormente, as espécies foram identificadas com auxílio de bibliografia taxonômica ampla, comparações com materiais depositados em herbários (IAC, SP, SPSF e UEC), além da consulta a especialistas, notadamente das famílias Myrtaceae (Maria Lucia Kawasaki e Marcos Sobral), Lauraceae (José Batista Baitelo e Sueli Antonia Nicolau) e Rubiaceae (Sigrid JungMendaçolli e Elisete Araújo da Anunciação).

A coleção referência (“voucher”) foi escolhida entre os melhores espécimes coletados para cada morfoespécie, e depositada no herbário do Instituto Agronômico de Campinas (IAC). Materiais férteis de espécies de identificação duvidosa estão sendo selecionados para inclusão no Herbário SP. Informações adicionais sobre as coletas podem ser consultadas pela Internet (www.iac.sp.gov.br/herbario). A amostra florística foi classificada de acordo com o sistema de Brummit (1992) e apresentada em listagem ordenada por famílias, gêneros e espécies.

\section{Análise dos dados}

Para cada bloco, área e região de amostragem, foram anotadas as riquezas totais e percentuais, obtidos os índices de diversidade de Shannon (H'), utilizando-se a base logarítmica natural, e o índice de eqüabilidade de Pielou (J) (Ludwig \& Reynolds 1988).

As espécies foram agrupadas em três categorias de dispersão (anemocóricas, zoocóricas e barocóricas), e em quatro categorias de sucessão (pioneiras, secundárias iniciais, secundárias tardias e umbrófilas). A classificação das síndromes de dispersão foi feita por dados de literatura, a partir de conceitos estabelecidos por Van der Pijl (1982), com base nas características dos frutos e sementes. Espécies tipicamente autocóricas foram mantidas na classificação "barocóricas”. 
As categorias para a classificação sucessional foram definidas, a princípio, de acordo com critérios estabelecidos por Gandolfi (1991, 2000) e Kageyama \& Viana (1992), considerando-se a categoria funcional das umbrófilas. Foram consideradas pioneiras as espécies de ciclo de vida curto completado sob condições de pleno sol para estabelecimento e reprodução. As secundárias iniciais foram consideradas como sendo aquelas espécies que precisam de plena luz para crescimento e reprodução. Secundárias tardias foram consideradas aquelas espécies longevas, que crescem à sombra, mas necessitam de plena luz para reprodução. As umbrófilas correspondem às espécies que completam todo o seu ciclo de vida à sombra de outras árvores (i.e., as espécies de subosque). Consideraram-se "sem classificação" aquelas que, por carência de informações, não puderam ser enquadradas nas categorias anteriores. A classificação baseou-se em dados da literatura, notadamente Gandolfi (1991), Leitão Filho (1993), Cardoso-Leite (1995), Gomes (1995), Gandolfi et al. (1995) e Gandolfi (2000), em observações diretas e experiência de campo dos autores, além de Géza de Faria Arbócz e Luciana Ferreira Alves. Quando houve discrepância na classificação, optou-se sempre pela classificação mais comum entre o grupo de botânicos. Uma classificação mais precisa depende de maior conhecimento da biologia das espécies, bem como da padronização dos conceitos existentes, adaptando os conceitos clássicos (Budowsky 1965, Denslow 1980, Whitmore 1989) à nossa realidade, como sugerem Gandolfi (1991), Gandolfi et al. (1995) e Gomes (1998).

Para amenizar possíveis erros de classificação, apresenta-se, também, um agrupamento mais simples em duas grandes categorias sucessionais, as "pioneiras lato sensu", somando as pioneiras e iniciais do primeiro agrupamento; e as "tardias lato sensu", considerando as secundárias tardias e umbrófilas (Whitmore 1989, Gandolfi 1991). A partir destas classificações, obteve-se o número e porcentagem de espécies total, por área e região de amostragem, por categoria sucessional e síndrome de dispersão.

A composição florística foi comparada pelo agrupamento e ordenação das amostras, utilizando-se matrizes de abundância das espécies, por bloco $(n=24)$ e por áreas $(\mathrm{n}=6)$, trabalhadas através do programa PC-ORD (McCune \& Mefford 1999, McCune \& Grace 2002). Para a classificação, foi utilizada a distância de Sorensen (Bray-Curtis) e o método de agrupamento por UPGMA (Sneath \& Sokal 1973), que utiliza a média aritmética da distância entre o objeto que se quer incluir no grupo e cada objeto do grupo (Valentim 2000).

Para o ordenamento, utilizou-se a Detrended Correspondence Analysis (DCA ou Análise de Correspondência Destendenciada), baseada na distância do qui-quadrado. Trabalhou-se com a matriz completa de espécies, incluindo as raras, com a opção de rescalonamento ("rescaling”) dos eixos e minimizando o peso das espécies raras. O ordenamento também foi feito retirando as espécies raras, com cortes sucessivos de abundância até 10 indivíduos no total da amostra. Porém, como não houve modificação significativa do padrão geral exibido, principalmente pelo primeiro eixo, optou-se por apresentar apenas os dados da matriz completa.

\section{Resultados}

\section{A flora arbórea do Morro Grande}

No conjunto dos 2400 indivíduos, foram identificadas 260 espécies, pertencentes a 134 gêneros e 64 famílias, sendo três morfo-espécies classificadas até família (Tabela 1).

A maioria das 64 famílias apresentou reduzido número de espécies, 13 tendo cinco ou mais espécies: Myrtaceae (56 espécies), Lauraceae (32), Fabaceae (19), Rubiaceae (14), Melastomataceae (8), Euphorbiaceae (7), Sapindaceae e Sapotaceae (6), Annonaceae, Aquifoliaceae, Asteraceae, Cyatheaceae e Myrsinaceae, cada uma com 5 espécies. Estas 13 famílias representam 66,53\% das espécies registradas.

Quinze gêneros apresentaram-se com mais de quatro espécies: Ocotea (19), Eugenia (18), Myrcia (12), Miconia (7), Ilex (5), Campomanesia, Cyathea, Gomidesia, Maytenus, Meliosma, Nectandra, Psychotria, Rapanea, Solanum e Symplocos, com quatro espécies cada. Estes quinze gêneros, dentre os 134 encontrados, representam $38,84 \%$ das espécies amostradas.

Ocorreram 12 espécies nas seis áreas de amostragem, algumas com abundâncias similares e outras com valores bem diferentes. As espécies Guapira opposita e Rudgea jasminoides apresentaram as maiores freqüências, tendo ocorrido entre 19 a 20 dos 24 blocos. Matayba elaegnoides e Sorocea bonplandii ocorreram em 17 blocos, Ocotea dispersa em 16 e Jacaranda puberula em 15. As outras espécies que ocorreram em todas as áreas foram Cabralea cangerana, Campomanesia guavirova, Casearia obliqua, Cyathea atrovirens, Ocotea dispersa, Ocotea puberula e Rapanea umbellata.

As 10 espécies mais abundantes na amostra total foram Rudgea jasminoides (139 indivíduos), Myrcia multiflora (118), Guapira opposita (99), Ocotea dispersa (54), Eugenia pluriflora (48), Matayba elaegnoides (42), Euterpe edulis (40), Symplocos variabilis (40), Alsophila setosa (38) e Ilex paraguariensis (37).

A riqueza por área amostrada (400 indivíduos) variou de 74 a 109 espécies ou morfo-espécies, enquanto a diversidade e equabilidade variaram de 3,6 a 4,3 e 0,83 a 0,91, respectivamente (Tabela 2). Das 260 espécies, a maioria revelou-se zoocórica, perfazendo 208 espécies, 42 anemocóricas e 10 barocóricas (Tabela 3). Apenas 16 espécies foram classificadas como típicas pioneiras, 100 como secundárias iniciais, 93 como secundárias tardias, 39 como umbrófilas e 12 ficaram “sem classificação” (Tabela 4). 
A maioria das espécies anemocóricas foi considerada inicial ou pioneira, com exceção das Cyatheaceae, em geral umbrófilas, e Apocynaceae, Bombacaceae, Lecythidaceae e algumas Fabaceae. Rubiaceae é bem representada por espécies umbrófilas, de pequeno e médio porte, enquanto Melastomataceae, também com espécies de pequeno e médio porte, é predominantemente heliófila.

Euphorbiaceae apresentou predominantemente espécies heliófilas e de crescimento rápido, secundárias iniciais (e.g. Alchornea triplinervia, Croton floribundus) e também espécies higrófilas, como Sebastiania commersoniana e Sapium glandulatum. Cyatheaceae, geralmente composta por espécies de pequeno porte $(<10$ cm de DAP), foi freqüente e abundante tanto nas florestas maduras quanto nas antropizadas.

Lauraceae e Myrtaceae possuem apenas espécies zoocóricas, além de predominantemente tardias ou umbrófilas, com poucas iniciais e nenhuma pioneira, assim como Annonaceae, Cyatheaceae, Rubiaceae e Sapotaceae. As Aquifoliaceae são também zoocóricas, mas predominantemente iniciais, como as Myrsinaceae, Sapindaceae, Solanaceae e Euphorbiaceae. Esta última, no entanto, tem uma maioria das espécies barocóricas. Fabaceae apresenta padrão misto com espécies em praticamente todas as categorias sucessionais e de dispersão. Asteraceae apresenta-se como uma família tipicamente pioneira e de dispersão pelo vento (Tabela 1 )

Apenas uma espécie exótica foi amostrada: Eryobotrya japonica (Rosaceae), a nespereira, típica zoocórica.

\section{Variações internas na composição específica}

Nas áreas secundárias $(A, B, C)$, foram amostradas 157 espécies arbóreas, contra 179 espécies nas áreas maduras $(Q, G, T)$. A área $A$ possui o menor número de espécies amostradas, $B$ e $C$ apresentam valores intermediários, enquanto Quilombo, Grilos e Torres possuem os maiores valores. O sítio Quilombo apresentou índice de diversidade e riqueza menores que Grilos e Torres, apesar de ser considerada a área de floresta mais madura e menos alterada. Os valores de equabilidade foram altos em todas as amostras, sendo maiores nas áreas consideradas primitivas (Tabela 2).

Quilombo apresentou o menor número de espécies anemocóricas e o maior número de espécies zoocóricas. Torres, Grilos e $C$ foram mais ricas em espécies anemocóricas. Em número total de espécies zoocóricas, $A, B$ e $C$ tiveram valores menores que $Q, G$ e $T$, embora apenas Quilombo tenha valores em percentagem superiores a $A, B$ e $C$ (Tabela 3).

Com relação à classificação sucessional, verifica-se que apenas o sítio $A$ possui maior percentagem de espécies pertencentes às categorias pioneira e secundária inicial, enquanto C, Grilos e Quilombo possuem maior percentagem de espécies tardias e umbrófilas (Tabela 4). B e Torres possuem percentagem equivalente de espécies pioneiras, iniciais, tardias e umbrófilas.

Nas áreas secundárias, foram mais comuns: no sítio A, Myrcia multiflora (62 indivíduos), Eugenia pluriflora (43) e Rudgea jasminoides (22); no sitio B, Myrcia multiflora (42), Guapira opposita (32) e Sebastiania commersoniana (18); em C, Ocotea dispersa (30), Ilex paraguariensis (23), Cupania vernalis e Jacaranda puberula (17). O sítio $A$ teve em comum com $B$ e $C$, respectivamente 47 e 41 espécies. $B$ teve em comum com $C$ 45 espécies. Apenas 33 espécies ocorreram nas três áreas consideradas secundárias.

As áreas maduras, Quilombo, Grilos e Torres, foram mais ricas e similares entre si do que as secundárias ( $A, B$ e $C)$. Foram mais abundantes: em Quilombo, Rudgea jasminoides (47 indivíduos), Euterpe edulis (21) e Ocotea catharinensis (18); em Grilos, Cyathea dichromatolepis (25 indivíduos), Rudgea jasminoides e Bathysa meridionalis (21); em Torres, Guapira opposita (21), Ocotea pulchella, Symplocos variabilis, Alsophila setosa (17) e Rudgea jasminoides (15). Quilombo teve 68 espécies em comum com Grilos e 56 em comum com Torres. Grilos e Torres tiveram 65 espécies em comum. No total, 47 espécies ocorreram nas três áreas maduras.

O agrupamento e o ordenamento revelaram diferenças florísticas e de abundância entre as regiões consideradas inicialmente como de florestas secundárias e predominantemente maduras (Figuras 1 e 2). O dendrograma, obtido pela aplicação do UPGMA, apresenta essencialmente dois grandes grupos (Figura 1): o primeiro grupo corresponde basicamente às áreas consideradas maduras $(Q, G, T)$, incluindo o bloco $B 1$; o segundo inclui florestas secundárias $(A, B, C)$, menos $B 1$. De uma forma mais detalhada, é possível distinguir os dois extremos (áreas secundárias $A$ e $B$ vs áreas maduras $Q$ e $G$ ), e um agrupamento intermediário ( $C$, B1 e parte de Torres).

O ordenamento reforça este padrão geral (Figura 2), apesar dos dois primeiros eixos da DCA representarem apenas 14,9\% e 8,9\% da variância total, respectivamente. Esta baixa variância dos dados seria de se esperar para florestas contínuas, heterogêneas e não muito distantes. Os blocos A1, A2, A4, B2 e B4 aparecem no extremo direito do primeiro eixo do ordenamento, representando as florestas secundárias na amostra. As áreas $C 1, C 2, C 3$ e $C 4$ estão na porção mediana inferior, junto com B3, B1, T4, G2, T2 e T3, representando florestas secundárias, porém mais tardias ou inseridas em matriz predominantemente madura. Finalmente, os blocos do Quilombo e T1, juntamente com G4, G3 e G1 agrupam-se à esquerda do primeiro eixo, representando as áreas maduras do Morro Grande.

Assim, as espécies ordenadas pelos escores no primeiro eixo representariam o gradiente sucessional. As 
espécies mais abundantes que caracterizaram os blocos secundários foram essencialmente: Anadenanthera colubrina, Sebastiania commersoniana, Myrcia oblongata, Eugenia pluriflora, Pimenta pseudocaryophyllus, Symplocos tetrandra, Symplocos glanduloso-marginatum, Syagrus romanzzoffiana, Myrcia multiflora e Myrcia sp.1.

Com escores intermediários no eixo 1 , ainda caracterizando áreas secundárias, notadamente $C$, aparecem Solanum swartzianum (que já aparece nos blocos Q2, Q4, T3 e T4), Rapanea gardneriana, Matayba elaegnoides, Prunus myrtifolia, Nectandra barbellata, Maytenus robusta, Ilex paraguariensis, Maytenus evonymoides, Roupala montana, Cupania vernalis, Guatteria australis e Ocotea bicolor. Ainda com escores intermediários no eixo 1, estão espécies bastante freqüentes e abundantes: Cyathea atrovirens, Psidium cattleyanum, Jacaranda puberula, Myrcia citrifolia, Campomanesia guavirova, Clethra scabra, Campomanesia xanthocarpa, Ocotea puberula, Sorocea bonplandii, Ocotea pulchella, Solanum pseudoquina, Lamanonia ternata, Guapira opposita e Weinmannia paullinaefolia.

Aparecem como características das áreas maduras, com escores mais baixos, Coussapoa microcarpa, Micropholis crassipedicelata, Aspidosperma olivaceum, Lytocarium hoehnei, Myrcia citrifolia, Pouteria bullata, Diploon cuspidatum, em particular. Caracterizam as áreas primitivas, como um todo, Ocotea catharinensis, Rapanea hermogenesii, Cryptocarya saligna, Euterpe edulis, Posoqueria latifolia, Ocotea daphnifolia, Cyathea dichromatolepis, Gomidesia anarcadiifolia, Cariniana estrellensis, Eugenia stigmatosa e Marlierea skortzoviana. Nas áreas maduras aparecem espécies de regeneração secundária, como Miconia budlejoides, Miconia cabussu e Solanum cinnamomeum, provavelmente devido a clareiras antrópicas oriundas da exploração seletiva ou de outras perturbações.

Algumas espécies diferenciam alguns blocos, como Sebastiania commersoniana e Cedrela odorata, higrófilas, ou ainda Cinnamomodendron pseudoglaziovii, Amaioua intermedia, Chionanthus filiformis, Inga sellowiana e Bathysa meridionalis, que caracterizam parte dos blocos de Grilos, de forte influência de corpos d’água, com florestas abertas e iluminadas.

\section{Discussão}

\section{Riqueza e diversidade}

Os estudos no Morro Grande revelam riqueza e diversidade surpreendentemente altas, ao contrário do padrão para outras florestas estudadas na região (Tabarelli et al. 1993, Aragaki 1997, Tabarelli \& Mantovani 1999, Dislich et al. 2001). Considerando uma riqueza amostrada de 260 espécies, outras 99 observadas/coletadas em fragmentos florestais adjacentes ao Morro Grande (Bernacci et al. submetido), muitas das quais já coletadas e/ou observadas na RFMG (Aguilar 1998, E. L. M. Catharino observ. pess.), além de espécies de áreas ripárias e pioneiras, ainda não amostradas, estima-se que na região ocorram entre cerca de 400-430 espécies arbóreas. Este número é superior aos obtidos ou estimados em estudos de florestas paulistanas, em particular no Parque Estadual das Fontes do Ipiranga (PEFI), que possuiria entre 300-350 espécies (Gomes 1995, 1998).

O valor do índice de Shannon para o conjunto da amostragem ( $\mathrm{n}=2400$ indivíduos), H’= 4,75 nats/indivíduo, está entre os mais altos para as florestas paulistas. ,Em áreas de floresta atlântica, os valores mais elevados deste índice chegam a 4,07 nats/indivíduo em Ubatuba (Silva \& Leitão Filho 1982), 4,36 em São José dos Campos (Silva 1989), 4,31 na Juréia (Mantovani 1993), 4,31 em Cubatão (Leitão Filho 1993) e 4,51 em São Paulo, SP (PEFI, Struffaldi-de-Vuono 1985). Alguns destes também incluíram gradientes sucessionais, notadamente Leitão Filho (1993) e Struffaldide-Vuono (1985). Ao contrário, as florestas estacionais conservadas do interior do estado de São Paulo apresentam H' mais baixos, como 3,53 em Campinas (Bernacci 1992), 3,24 em Matão (Rozza 1997) e 2,41 (estrato superior), 2,01 (estrato inferior) e 1,83 (estrato intermediário) em Gália (Durigan et al. 2000), apesar de valor maior por Pagano et al. (1987), de 4,29 nats/ind., que inclui um gradiente sucessional. Porém, os índices para o Morro Grande são inferiores aos apresentados por Rolim \& Nascimento (1997) para florestas atlânticas do norte do Espírito Santo, estimados entre 4,71 e 4,94, considerando-se intensidades amostrais de 486 a 2008 indivíduos, assim como 5,51 nats/ind., em Santa Teresa (ES) (Thomaz \& Monteiro 1997). De maneira geral, levando em consideração os diferentes métodos, estes valores sugerem uma diminuição da diversidade no sentido norte-sul da fachada atlântica, assim como leste-oeste, fato já destacado por Oliveira-Filho \& Fontes (2000), porém denotando a elevada diversidade e riqueza regional.

Tanto as florestas secundárias tardias como as predominantemente maduras apresentaram altas riqueza e diversidade. As áreas secundárias (e.g., A e B) apresentaram diversidade e riqueza inferiores às predominantemente maduras (e.g. Quilombo, Grilos e Torres). Os maiores índices de diversidade, encontrados para Grilos e Torres, devemse, provavelmente, à combinação de maior riqueza de espécies tardias e espécies pioneiras/secundárias iniciais, favorecidas por clareiras antrópicas, além de aberturas relacionadas aos cursos d’água. Estas áreas seriam mais ricas por apresentarem mosaicos sucessionais, além dos ambientais. A alteração antrópica, em áreas maduras, parece aumentar a riqueza de espécies, proporcionando a entrada de espécies secundárias iniciais, notadamente anemocóricas. Quilombo, área com menores intervenções antrópicas, tem menor ocorrência das espécies iniciais, resultando em uma diversidade pouco menor. Possivelmente, 
a baixa diversidade encontrada previamente em florestas da região metropolitana de São Paulo parece estar correlacionada ao fato das florestas estudadas serem predominantemente secundárias, devido à perturbação antrópica, e por não apresentarem um amplo gradiente ambiental ou sucessional.

\section{Características sucessionais das florestas do Morro Grande}

O agrupamento expresso pelo UPGMA revelou dois grupos em sua primeira divisão, formados pelos conjuntos das áreas consideradas maduras e secundárias. A separação em dois grandes grupos foi clara, embora blocos secundários tenham ficado juntos a blocos de áreas maduras e viceversa, em poucos casos.

O ordenamento também apresentou o mesmo gradiente, sugerindo que o primeiro eixo do DCA expressa o gradiente sucessional, mantendo à esquerda os blocos considerados maduros (Quilombo e algumas áreas de Grilos e Torres) e à direita os blocos secundários ( $A$ e $B$ ), tendo em posição intermediária os blocos da área $C$, com alguns blocos de Torres e Grilos. Os grupos intermediários, com histórico de cortes ou fortes alterações antrópicas no passado $(C$, T3, B1), estão inseridos em matriz de florestas predominantemente maduras (áreas $T$ e $G$, em particular), o que facilitaria a colonização por espécies tardias e umbrófilas. Estas áreas intermediárias apresentaram mais espécies comuns aos blocos $A, B$, e $C$. O segundo eixo, aqui não explorado em profundidade, parece expressar diferenças internas, relacionadas a algum caráter sucessional residual ou a outras diferenças ambientais entre os blocos.

Como a DCA cruza informações das espécies e dos blocos, é possível a detecção de espécies indicadoras de estágios sucessionais avançados e florestas maduras, expresso pelos "scores” das espécies ordenadas segundo o gradiente. Assim, revelam-se como típicas dos blocos de florestas secundárias muitas Myrtaceae, entre as quais Myrcia multiflora, Myrcia oblongata, Eugenia sonderiana, Eugenia pluriflora, Pimenta pseudocaryophyllus, Campomanesia guazumifolia, Campomanesia xanthocarpa e Myrcia arborescens. Estas Myrtaceae heliófilas e longevas parecem determinar um estágio sucessional estacionário, onde uma grande quantidade de indivíduos conseguiu se estabelecer em alta densidade, dominando o dossel, notadamente Myrcia multiflora, Myrcia sp.1 e Eugenia pluriflora, que aparecem com grande abundância, provavelmente também relacionadas a áreas de solos mais degradados pela ação humana. Outras espécies como Seguieria floribunda, Machaerium nictitans, Miconia ligustrifolia, Ilex brevicuspis, Xylosma ciliatifolia, Syagrus romanzzoffiana também compõem as áreas secundárias, representadas com grande abundância.
Por outro lado, espécies de Sapotaceae, como Micropholis crassipedicellata, Diploon cuspidatum e Pouteria bullata, caracterizam as florestas maduras, além de Aspidosperma olivaceum, Lytocaryum hoehnei e Myrcia citrifolia. As lauráceas são representadas por espécies exclusivas ou mais abundantes como Ocotea catharinensis, Cryptocarya saligna e Ocotea daphnifolia. Também caracterizam as áreas maduras Rapanea hermogenesii, Euterpe edulis, Posoqueria latifolia, Cyathea dichromatolepis, Gomidesia anacardiifolia, Cariniana estrellensis e Marlierea skortzoviana, aparecendo com baixos escores no eixo 1.

Espécies abundantes e muito comuns por toda a floresta, como Guapira opposita e Rudgea jasminoides, podem caracterizar as florestas montanas da região, o que é verificado por Scudeller et al. (2001), não sendo sensíveis na detecção de estádios sucessionais, embora Rudgea jasminoides tenha se revelado mais abundante nas áreas maduras. Matayba elaegnoides aparece em todas as áreas, com maior abundância nas áreas secundárias, enquanto Ilex paraguariensis, também freqüente, caracterizou notadamente o sítio C. Outras como Cedrela odorata, Inga sellowiana, Cinnamomodendron pseudoglaziovii, Bathysa meridionalis e Chionanthus filiformis, aparecem como preferenciais em áreas com influência de cursos d'água, as três primeiras nos trechos secundários e as últimas nas áreas maduras.

\section{Denominação da floresta do Morro Grande}

Apesar do clima úmido de planalto, as florestas do Morro Grande estão sujeitas a sazonalidade em precipitações e temperaturas, proporcionando a manutenção de espécies típicas de florestas mistas, montanas e/ou subtropicais, mesmo em baixa densidade e freqüência, como Araucaria angustifolia, Podocarpus lambertii, Drimys brasiliensis, ou em densidades maiores como a erva-mate (Ilex paraguariensis). O tapiá-guaçú (Euphorbiaceae, Alchornea sidaefolia), abundante em algumas áreas secundárias ao norte da Reserva e não amostrado, é característico das florestas secundárias do sul (Klein 1978).

A região mantém também espécies associadas às florestas tropicais de climas quentes e sazonais do interior, sendo amostradas Croton floribundus, Machaerium stipitatum, Machaerium vestitum, Myrocarpus frondosus, Lafoensia pacari, e outras observadas como Copaifera langsdorffii, Platymiscium floribundum, Machaerium villosum, Gochnatia polymorpha e Campomanesia pubescens, estas últimas especialmente nas áreas impactadas, ao norte e centro do Morro Grande (E.L.M.Catharino observação pessoal). As florestas da RFMG também possuem espécies anemocóricas de dossel com ocorrência maior nas florestas estacionais do interior, como Aspidosperma olivaceum, Tabebuia chrysotricha, Tabebuia cf. impetiginosa, Cariniana estrellensis, 
Pseudobombax grandiflorum e Chorisia speciosa, ou autocóricos/anemocóricos como Anadenanthera colubrina e Piptadenia paniculata. Outras espécies típicas das florestas estacionais do interior paulista foram amostradas poucos quilômetros a oeste, em São Roque, como o pau-marfim (Balfourodendron riedelianum), o jequitibá-vermelho (Lecythidaceae, Carianiana legalis), a peroba-rosa (Apocynaceae, Aspidosperma polyneuron), o guaritá e o gonçalo-alves (Anacardiaceae, Astronium spp.), tardias “sensu amplo”, e o pau-jangada (Malvaceae, Bastardiopsis densiflora), entre as pioneiras “sensu amplo” (Cardoso Leite 1995).

Considera-se, normalmente, que as florestas ombrófilas densas têm uma maior proporção de zoocoria, cerca de $80 \%$, enquanto as semideciduais têm maior proporção de anemocoria (Morelatto 1992), sendo um fator diferencial das florestas ombrófilas densas e estacionais semideciduais. Por este aspecto, as florestas do Morro Grande poderiam ser consideradas dentro do conjunto das florestas ombrófilas densas.

Os dados florísticos do Morro Grande, considerados em seu conjunto, corroboram a característica mista das florestas do Planalto Atlântico de Ibiúna/Paulistano, em íntima relação com as florestas da encosta ou Floresta Ombrófila Densa (Veloso \& Góes Filho 1982), conforme já apontado por Siqueira (1994), Salis et al. (1995), Ivanaukas (1997), Torres et al. (1997), Aragaki (1997) e Gomes (1998). Como possui várias espécies da floresta mista com araucária e da floresta semidecídua de planalto, ou mesmo elementos dos cerrados em menor proporção, tem caráter misto ou transicional, conforme Eiten (1970), mas dentro do domínio driádico ou atlântico (“floresta ou mata atlântica”).

Esta característica atlântica da flora fica clara numa análise por família e gêneros. As cinco famílias mais ricas em espécies, Myrtaceae, Lauraceae, Fabaceae, Rubiaceae e Melastomataceae são, em geral, citadas como características das florestas montanas ou submontanas de São Paulo e Rio de Janeiro, ou florestas atlânticas do sul (Silva 1980, Mori et al. 1981, 1983b, Struffaldi-de-Vuono 1985, Gandolfi 1991, Baitello et al. 1992, Nastri et al. 1992, Mantovani 1993, Garcia 1995, Gomes 1995, 1998, Catharino 1996, Aragaki 1997, Pivello \& Peccinini 2002, Arzolla 2002). Em particular Myrtaceae revelou-se abundante tanto nas áreas secundárias tardias como maduras. No geral, a maioria dos gêneros ricos em espécies também é encontrada em outros estudos na Província Atlântica: Ocotea, Eugenia, Myrcia, Ilex e Cyathea, nas florestas maduras e Miconia, Campomanesia, Rapanea e Solanum, mais comuns em áreas antrópicas ou clareiras.

A mistura de elementos de diferentes floras pode ser creditada ao clima atual que, relacionado com a topografia e solos, permite a co-existência de espécies adaptadas a diferentes climas tropicais, ou devida a paleoclimas, que teriam proporcionado o aporte de diferentes floras na região metropolitana.

\section{Implicações para conservação}

O levantamento apresentado do componente arbóreo das florestas do Morro Grande atesta a sua importância biológica, com índices de diversidade dentre os mais altos encontrados no estado, comparáveis com florestas de latitudes menores como Rio de Janeiro, Espírito Santo e sul da Bahia. Esta alta diversidade é expressa tanto pelas formações secundárias como pelas maduras.

Várias espécies ameaçadas foram registradas, como a canela-sassafrás (Ocotea odorifera), canela-imbuia (Ocotea porosa), canela-amarela (Ocotea catharinensis), araucária (Araucaria angustifolia), palmiteiro-jussara (Euterpe edulis), xaxim-verdadeiro (Dicksonia sellowiana), entre outras. Muitas são quase desconhecidas pela ciência, como Quiina cf. magallano-gomesii, apesar de sua utilização humana desde tempos pré-coloniais. Outras, como a erva-mate (Ilex paraguariensis), já tiveram expressão econômica regional, com exportações registradas desde o período colonial.

A Mata Atlântica tem sido reconhecida internacionalmente como de relevante valor biológico (Mori et al. 1981, 1983a, Thomas et al. 1998), sendo considerada um “hot-spot” por Myers (1998) e Myers et al. (2000). A área entre os estados de São Paulo e Rio de Janeiro é considerada como uma das áreas de endemismo, bem como área de refúgio do pleistoceno por inúmeros autores. Ab’Sáber (1992) cita textualmente a região serrana de Caucaia como um possível “refúgio alto-montano”, quando climas mais secos teriam ocasionado a retração da vegetação arbórea em todo o sulsudeste do Brasil. Adiversidade encontrada no Morro Grande, bem como a combinação de espécies típicas das florestas úmidas da encosta com espécies características dos climas sazonais do interior e/ou mais frios, em uma mesma região geográfica, parece corroborar a hipótese levantada por Ab’Sáber (1992), da existência de um "refúgio alto-montano" na região serrana de Caucaia. Segundo esta hipótese, ainda por ser testada, em épocas de clima mais seco, teria havido uma retração da vegetação arbórea em todo o sul-sudeste do Brasil, com exceção de algumas áreas (refúgios), como no caso de Caucaia do Alto. Desta forma, torna-se ainda mais importante a preservação efetiva deste remanescente florestal, único nesta situação de relevo e em uma das regiões mais populosas do planeta, como grande reserva de espécies das florestas montanas do sul-sudeste do Brasil.

\section{Agradecimentos}

Em um trabalho coletivo, torna-se difícil agradecer a todos, assim agradecemos a toda a equipe do Projeto "Biota Fragmentos”, pela convivência enriquecedora, a dois assessores anônimos e, em especial, à Luciana Ferreira Alves, pelas sugestões numa versão prévia deste artigo. Agradecemos à Sabesp, que permitiu a realização deste trabalho, em nome do Engenheiro José Alberto Galvão Ferro 
e, especialmente, ao Sr. José Roberto Nali, nosso iniciante na Reserva, pelo apoio sempre presente e pelo entusiasmo contagiante na conservação dessa bela floresta, em nome do qual agradecemos a toda equipe da Sabesp do AltoCotia. Esta pesquisa foi financiada pela FAPESP, dentro do Programa BIOTA (processo 99/05123-4).

\section{Bibliografia}

AB'SÁBER, A.N. 1992. A Serra do Japi, sua origem geomorfológica e a teoria dos refúgios. In Ecologia e preservação de uma área florestal no Sudeste do Brasil (L.P. Morellato, org.). Editora da Unicamp/Fapesp, Campinas, p.12-23.

AGUILAR, J.B.V. 1998. A comunidade de abelhas (Hymenoptera: Apoidea) da Reserva Florestal do Morro Grande, Cotia, São Paulo. Tese de doutorado, Instituto de Biociências, Universidade de São Paulo, São Paulo.

ARAGAKI, S. 1997. Florística e estrutura de trecho remanescente de floresta no Planalto Paulistano (SP). Dissertação de mestrado, Instituto de Biociências, Universidade de São Paulo, São Paulo.

ARAGAKI, S. \& MANTOVANI, W. 1998. Caracterização do clima e da vegetação de remanescente florestal no planalto paulistano (SP). In Anais do IV Simpósio de Ecossistemas Brasileiros, Pub. Aciesp 104:25-36.

ARZOLLA, F.A.R.P. 2002. Florística e fitossociologia de trecho da Serra da Cantareira, Núcleo Águas Claras, Parque Estadual da Cantareira, Mairiporã - SP. Dissertação de mestrado, Universidade Estadual de Campinas, Campinas.

BAITELLO, J.B. \& AGUIAR, O.T. 1982. Flora arbórea da Serra da Cantareira (São Paulo). Silvic. Sao Paulo 16A:582-590.

BAITELLO, J.B., AGUIAR, O.T., ROCHA, F.T., PASTORE, J.A. \& ESTEVES, R. 1992. Florística e fitossociologia do estrato arbóreo de um trecho da Serra da Cantareira (Núcleo Pinheirinho) - SP. In Anais do $2^{\circ}$ Congresso Nacional sobre Essências Nativas. São Paulo. Rev. Inst. Florest. 4:291-298.

BERNACCI, L.C. 1992. Estudo florístico e fitossociológico de uma floresta no município de Campinas, com ênfase nos componentes herbáceo e arbustivo. Dissertação de mestrado, Instituto de Biologia, Universidade Estadual de Campinas, Campinas.

BERNACCI, L.C., FRANCO, G.A.D.C., ARBOCZ, G.F., CATHARINO, E.L.M., DURIGAN, G. \& METZGER, J.P. Composição florística e aspectos ecológicos das florestas do sul do Planalto Paulistano, Cotia e Ibiúna (SP). Submetido.

BRUMMITT, R.K. 1992. Vascular plants: families and genera. The Royal Botanic Gardens, Kew.
BUDOWSKY, G. 1965. Distribution of tropical american forest species in the light of successional processes. Turrialba 15:40-42.

CARDOSO-LEITE, E. 1995. Ecologia de um fragmento florestal em São Roque, SP: florística, fitossociologia e silvigênese. Dissertação de Mestrado, Instituto de Biologia, Universidade Estadual de Campinas, Campinas.

CATHARINO, E.L.M. 1989. Estudos fisionômicos-florísticos e fitossociológicos em matas residuais secundárias no Município de Piracicaba, SP. Dissertação de Mestrado, Instituto de Biologia, Universidade Estadual de Campinas, Campinas.

CATHARINO, E.L.M (coord.). 1996. Diagnose da vegetação e modelos de recomposição vegetal da bacia do Guarapiranga, região metropolitana de São Paulo, SP, Brasil. Programa de saneamento ambiental da região metropolitana da bacia do Guarapiranga (relatório técnico). Instituto de Botânica do Estado de São Paulo, São Paulo.

COTTAM, G \& CURTIS, J.T. 1956. The use of distance measures in phytosociological sampling. Ecology 37:451-460.

DENSLOW, J.S. 1980. Gap partioning among tropical rainforest sucession trees. Biotropica (suppl.) 12:47-55.

DISLICH, R, CERSÓSIMO, L. \& MANTOVANI, W. 2001. Análise da estrutura de fragmentos florestais no Planalto Paulistano, SP. Rev. Bras. Bot. 24:321-332.

DURIGAN, G, FRANCO, GA.D.C., SAITO, M. \& BAITELLO, J.B. 2000. Estrutura e diversidade do componente arbóreo da floresta na Estação Ecológica dos Caetetus, Gália, SP. Rev. Bras. Bot. 23:369-381.

EITEN, G. 1970. A vegetação do Estado de São Paulo. Bol. Inst. Bot. 7:1-147.

GANDOLFI, S. 1991. Estudo florístico e fitossociológico de uma floresta residual na área do Aeroporto Internacional de São Paulo, município de Guarulhos, SP. Dissertação de mestrado, Instituto de Biologia, Universidade Estadual de Campinas, Campinas.

GANDOLFI, S. 2000. História natural de uma floresta estacional semidecidual no município de Campina (São Paulo, Brasil). Tese de doutorado, Instituto de Biologia, Universidade Estadual de Campinas, Campinas.

GANDOLFI, S., LEITÃO FILHO, H.F. \& BEZERRA, C.L.F. 1995. Levantamento florístico e caráter sucessional das espécies arbustivo-arbóreas de uma floresta mesófila semidecídua no Município de Guarulhos, SP. Braz. J. Biol. 55:753-767.

GARCIA, R.J.F. 1995. Composição florística dos estratos arbóreos e arbustivo da Mata do parque Santo Dias (São Paulo - SP, Brasil). Dissertação de mestrado, Instituto de Biociências, Universidade de São Paulo, São Paulo. 
GOMES, E.P.C. 1995. Fitossociologia do componente arbóreo de um trecho de mata em São Paulo, SP. Dissertação de mestrado. Instituto de Biociências, Universidade de São Paulo, São Paulo.

GOMES, E.P.C. 1998. Dinâmica do componente arbóreo de um trecho de mata em São Paulo, SP. Tese de doutorado, Instituto de Biociências, Universidade de São Paulo, São Paulo.

GROMBONI-GUARATINI, M.T., BERNACCI, L.C., MEIRA NETO, J.A.A., TAMASHIRO, J.Y. \& LEITÃO FILHO, H.F. 1990. Estrutura fitossociológica de uma floresta semidecídua de altitude do Parque Estadual de Grota Funda (Atibaia - Estado de São Paulo). Acta Bot. Bras. 4:47-64.

HUECK, K. 1956. Mapa fitogeográfico do Estado de São Paulo. Bol. Paul. Geogr. 22:19-25.

IVANAUKAS, N.M. 1997. Caracterização florística e fisionômica da Floresta Atlântica sobre a Formação Pariquera-Açu, na Zona da Morraria Costeira do Estado de São Paulo. Dissertação de mestrado, Instituto de Biologia, Universidade Estadual de Campinas, Campinas.

JOLY, A.B. 1950. Estudo fitogeográfico dos campos do Butantã (São Paulo). Bol. Fac. Fil. Ciênc. Letr. Univ. S. Paulo 109 (Botânica) 8:3-68.

KAGEYAMA, P.Y. \& VIANA, V.M. 1992. Tecnologia de sementes e grupos ecológicos de espécies arbóreas tropicais. In Anais do $2^{\circ}$ Simpósio Brasileiro sobre Tecnologia de Sementes Florestais, Série Documentos, IF, São Paulo, p.197-215.

KLEIN, R.M. 1978. Contribuição ao conhecimento da flora e vegetação do vale do Itajaí - Santa Catarina. Tese de doutorado, FFCL, Universidade de São Paulo, São Paulo.

KÖPPEN, W. 1948. Climatologia. Ed. Fondo Cultura Economia, Mexico City.

LEITÃO FILHO, H.F. (org.) 1993. Ecologia da Mata Atlântica em Cubatão. Editora UNESP/Editora UNICAMP, Campinas.

LUDWIG, J.A. \& REYNOLDS, J.F. 1988. Statistical ecology. A primer on methods and computing. J.Wiley \& Sons, New York.

MANTOVANI, W. 1993. Estrutura e dinâmica da Floresta Atlântica na Juréia, Iguape, SP. Tese de livre-docência, Instituto de Biociências, Universidade de São Paulo, São Paulo.

MARTINS, F.R. 1991. Estrutura de uma floresta mesófila. Editora da UNICAMP, Campinas.

McCUNE, B. \& MEFFORD, M. J. 1999. PC-ORD for Windows: multivariate analysis of ecological data. Version 4.25. MjM Software, Gleneden Beach, Oregon.

McCUNE, B. \& GRACE, J.B. 2002. Analysis of ecological communities. MJM, Gleneden Beach, Oregon.
METZGER, J.P., ALVES, L.A., CATHARINO, E.L.M., GOULART \& W., SIMÕES, S.J.C. 2006. Uma área de relevante interesse biológico, porém pouco conhecida: a Reserva Florestal do Morro Grande. Biota Neotrop. 6(2): http://www.biotaneotropica.org.br/ v6n2/pt/abstract?article+bn00406022006 (último acesso em 03/05/2006).

MORELLATO, P.C. 1992. Padrões de frutificação e dispersão na Serra do Japi. In Ecologia e preservação de uma área florestal no Sudeste do Brasil (L.P. Morellato, org.). Editora da Unicamp/Fapesp, Campinas, p.112-140.

MORI, S.A., BOOM, B. M., CARVALHO,A. M. \&SANTOS, T.S. 1983a. Southem Bahian moist forests. Bot. Rev. 49:155-232.

MORI, S.A., BOOM, B. M., CARVALHO, A. M. \& SANTOS, T. S. 1983b. Ecological importance of Myrtaceae in an Eastern Brazilian Wet Forest. Biotropica 15:68-69.

MORI, S.A., BOOM, B.M. \& PRANCE, G.T. 1981. Distribution patterns and conservation of eastern Brazilian coastal forest tree species. Brittonia 33:233-245.

MYERS, N. 1988. Threatened biotas: "hotspots” in tropical forestas. Environmentalist 8:187-208.

MYERS, N., MITTERMEIER, R.A., MITTERMEIER, C.G., FONSECA, G.A.B DA \& KENT, J. 2000. Biodiversity hotspots for conservation priorities. Nature 403:853-858.

NASTRI, V.D.F., CATHARINO, E.L.M., ROSSI, L., BARBOSA, L.M., PIRRÉ, E., BENEDITELLI, C.,ASPERTI, L.M., DORTA, R.O. \& COSTA, M.P. 1992. Estudos fitossociológicos em uma área do Instituto de Botânica de São Paulo utilizada em programa de Educação ambiental. In Anais do $2^{\circ}$ Congresso Nacional de Essências Nativas. Rev. Inst. Florest. 4: 219-225.

OLIVEIRA-FILHO,A.T. \& FONTES, M.A. 2000. Patterns of floristic differentiation among Atlantic Forests in Southeastern Brazil and the influence of climate. Biotropica 32:793-810.

PAGANO, S.N. 1985. Estudo florístico, fitossociológico e de ciclagem de nutrientes em mata mesófila semidecídua, no município de Rio Claro, SP. Tese de livre-docência, Departamento de Biologia, UNESP, Rio Claro.

PAGANO, S.N., LEITÃOFILHO, H.F. \& SHEPERD, GJ. 1987. Estudo fitossociológico em mata mesófila semidecídua no município de Rio Claro (estado de São Paulo). Rev. Bras. Bot. 10:49-61.

PIVELLO, V.R. \& PECCININI, A.A. 2002. A vegetação do PEFI. In Parque Estadual das Fontes do Ipiranga: unidade de conservação que resiste à urbanização de São Paulo (D.C. Bicudo, M.R. Forti, \& C.E.M. Bicudo, org.). Editora da Secretaria do Meio ambiente do Estado de São Paulo, São Paulo, p.75-92.

RODRIGUES, R.R. 1986. Levantamento florístico e fitossociológico das matas da Serra do Japi, Jundiaí, SP. Dissertação de mestrado, Instituto de Biologia, Universidade Estadual de Campinas, Campinas. 
ROIZMAN, L.G. 1993. Fitossociologia e dinâmica do banco de sementes de populações arbóreas de uma floresta secundária em São Paulo. Dissertação de mestrado, Instituto de Biociências, Universidade de São Paulo, São Paulo.

ROLIM, S.G. \& NASCIMENTO, H.E.M. 1997. Análise da riqueza, diversidade e relação espécies-abundância de uma comunidade arbórea tropical em diferentes intensidades amostrais. Sci. For. 52:7-16.

ROSSI, L. 1994. Aflora arbóreo-arbustiva da mata da Reserva da Cidade Universitária “Armando de Salles Oliveira” (São Paulo, Brasil). Bol. Inst. Bot. 9:1-105.

ROZZA, A. de F. 1997. Florística, fitossociologia e caracterização sucessional de uma floresta estacional semidecidual, Mata da Virgínia, Matão, SP. Dissertação de mestrado, Instituto de Biologia, Universidade Estadual de Campinas, Campinas.

SALIS, S.M., SHEPERD, G.J. \& JOLY, C.A. 1995. Floristic comparison of mesophytic semideciduous forests of the interior of the state of São Paulo, Southeast Brazil. Vegetatio 119:155-164.

SCUDELLER, V.V., MARTINS, F.R. \& SHEPERD, GJ. 2001. Distribuition and abundance of arboreal species in the atlantic ombrophilous dense forest in Southeastern Brazil. Plant Ecol. 152:185-199.

SETZER, J. 1946. A distribuição normal das chuvas no Estado de São Paulo. Rev. Bras. Geogr. 8:3-70.

SILVA, A.F. 1989. Composição florística e estrutura fitossociológica do estrato arbóreo da Reserva Florestal Professor Augusto Ruschi, São José dos Campos, SP. Tese de doutorado, Instituto de Biologia, Universidade Estadual de Campinas, Campinas.

SILVA, A.F. \& LEITÃO FILHO, H.F. 1982. Composição florística e estrutura de um trecho de mata atlântica de encosta no município de Ubatuba (São Paulo, Brasil). Rev. Bras. Bot. 5:43-52.

SIQUEIRA, M.F. 1994. Análise florística e ordenação de espécies arbóreas da Mata Atlântica através de dados binários. Dissertação de mestrado, Instituto de Biociências, Universidade Estadual de Campinas, Campinas.

SNETH, P.H.A. \& SOKAL, R.R. 1973. Numerical Taxonomy. Freeman, San Francisco.

STRUFFALDI-DE-VUONO, Y. 1985. Fitossociologia do estrato arbóreo da floresta da reserva biológica do Instituto de Botânica (São Paulo, SP). Tese de doutorado, Instituto de Biociências, Universidade de São Paulo, São Paulo.

TABARELLI, M., VILLANI, J.P. \& MANTOVANI, W. 1993. Aspectos da sucessão secundária em trecho da floresta atântica no Parque Estadual da Serra do Mar, SP. Rev. Inst. Florest. 5:99-112.
TABARELLI, M. \& MANTOVANI, W. 1999. Clareiras naturais e riqueza de espécies pioneiras em uma Floresta Atlântica montana. Braz. J. Biol. 59:251-261.

TARIFA, J.R. \& ARMANI, G. 2001. Os climas naturais. In Os climas da cidade de São Paulo (J.R. Tarifa \& T.R. de Azevedo, org.). GEOUSP, FFLCH, Universidade de São Paulo, Novos Caminhos 4, São Paulo, p.34-70.

THOMAS, W.M., CARVALHO, A.M.V., DE AMORIM, A.M.A., GARRISON, J. \& ARBELÁEZ, A.L. 1998. Plant endemism in two forests in southern Bahia, Brazil. Biodivers. C. 7:311-322.

THOMAZ, L.D. \& MONTEIRO, R. 1997. Composição florística da Mata Atlântica de encosta da Estação Biológica de Santa Lúcia, município de Santa Teresa ES. Bol. Mus. Biol. Mello Leitão 7:3-48.

TORRES, R.B., MARTINS, F.R. \& KINOSHITA, L.S. 1997. Climate, soil and tree flora relationship in forests in the state of São Paulo, southeastern Brazil. Rev. Brasil. Bot. 20:41-49.

VALENTIM, J.L. 2000. Ecologia numérica: uma introdução à análise multivariada de dados ecológicos. Interciência, Rio de Janeiro.

VAN der PIJL, L. 1982. Principles of dispersal in highter plants. Springer-Verlag, Berlim.

VELOSO, H.P. \& GÓES-FILHO, L. 1982. Fitogeografia brasileira - Classificação fisionômico-ecológica da vegetação neotropical. Bol. Técnico Radam-Brasil (série Vegetação) 1:1-80.

WHITMORE, T.C. 1989. Canopy gaps and two major groups of forest trees. Ecology 70:536-538.

WISHART, D. 1969. An algorithm for hierarchical classifications. Biometrics 25:165-170.

Título: Aspectos da composição e diversidade do componente arbóreo das florestas da Reserva Florestal do Morro Grande, Cotia, SP.

Autores: Catharino, E.L.M., Bernacci, L.C., Franco, G.A.D.C., Durigan, G. and Metzger, J.P.

Biota Neotropica, Vol. 6 ( número 2 ): 2006

http://www.biotaneotropica.org.br/v6n2/pt/ abstract?article+bn00306022006

Recebido em 23/5/2005 - Versão reformulada recebida em 12/10/2005 - Publicado em 01/05/2006

ISSN 1676-0603 


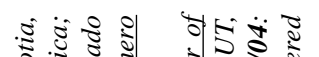

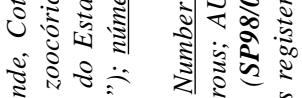

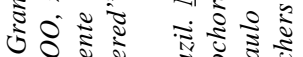

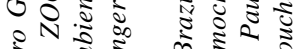

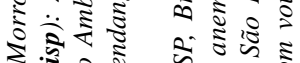
ช

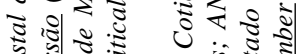

ปั้

平敌

₹ั:

ญัँّ

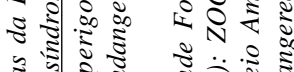

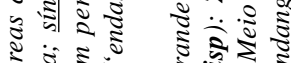

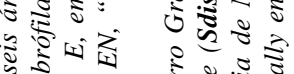

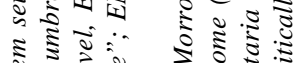

4रำ

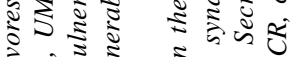

ชิ

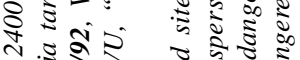

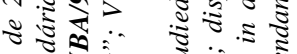

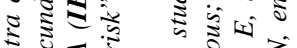

क

ธक के

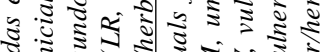

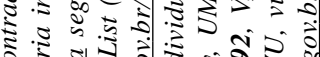

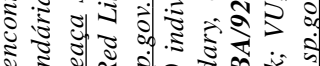

\% ज्ञ

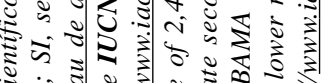

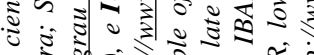

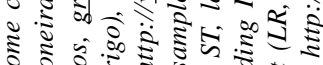

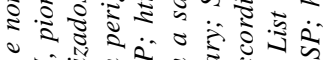

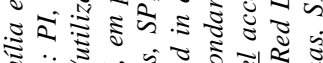

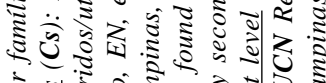

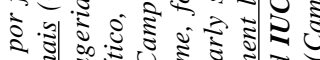

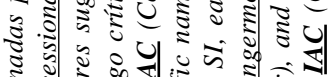

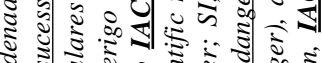
ธ。

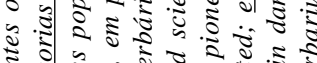

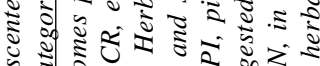

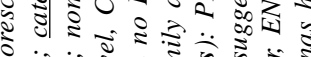

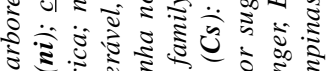
ว ติ

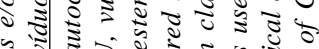

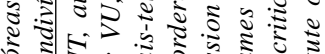

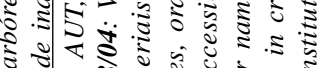
o is o

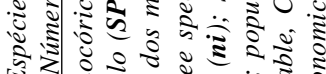

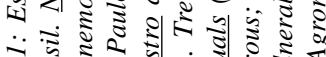
동

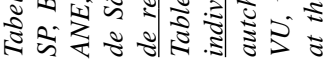

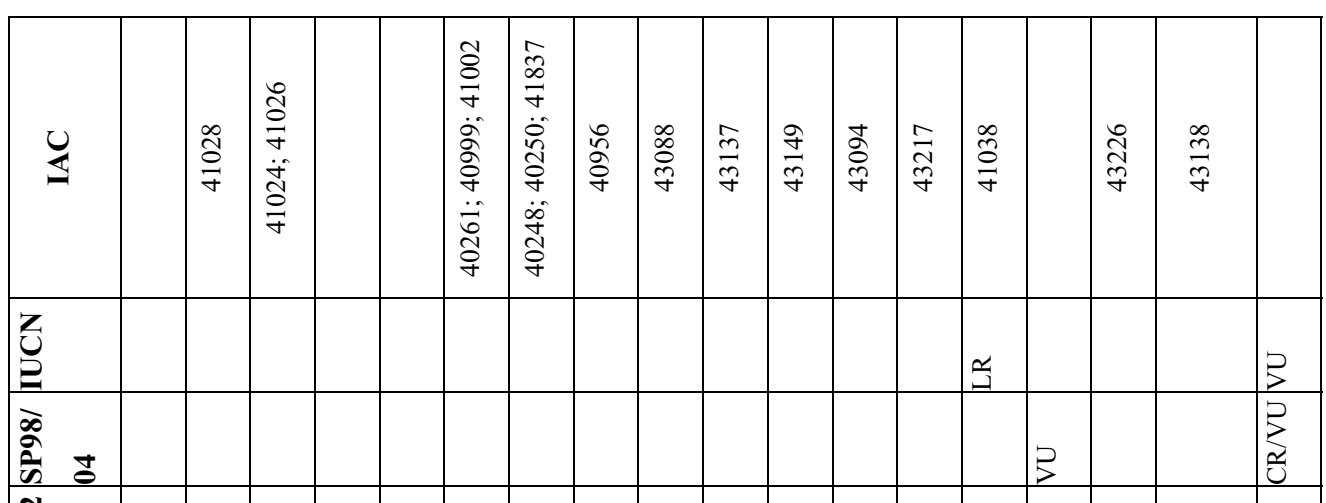

约
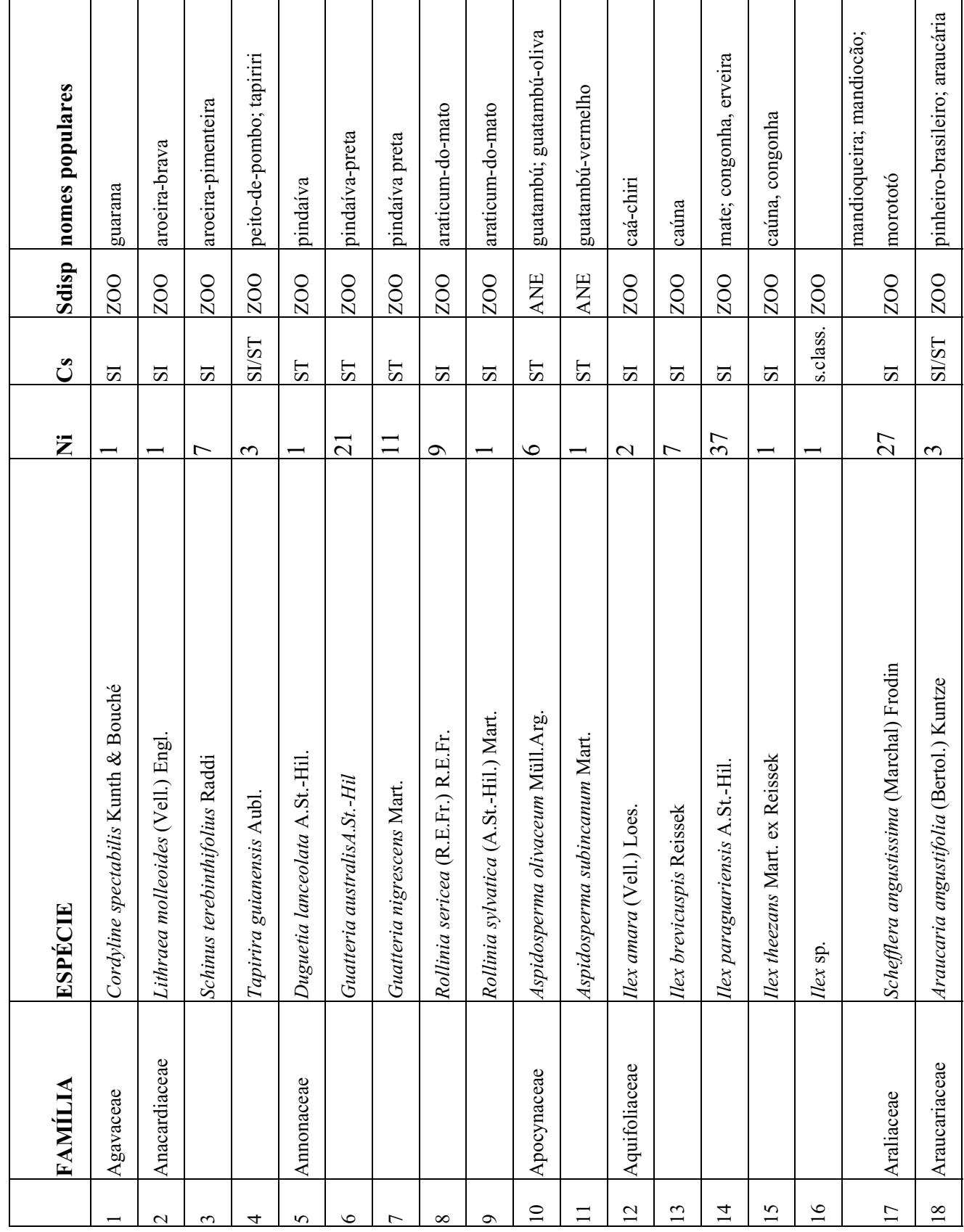


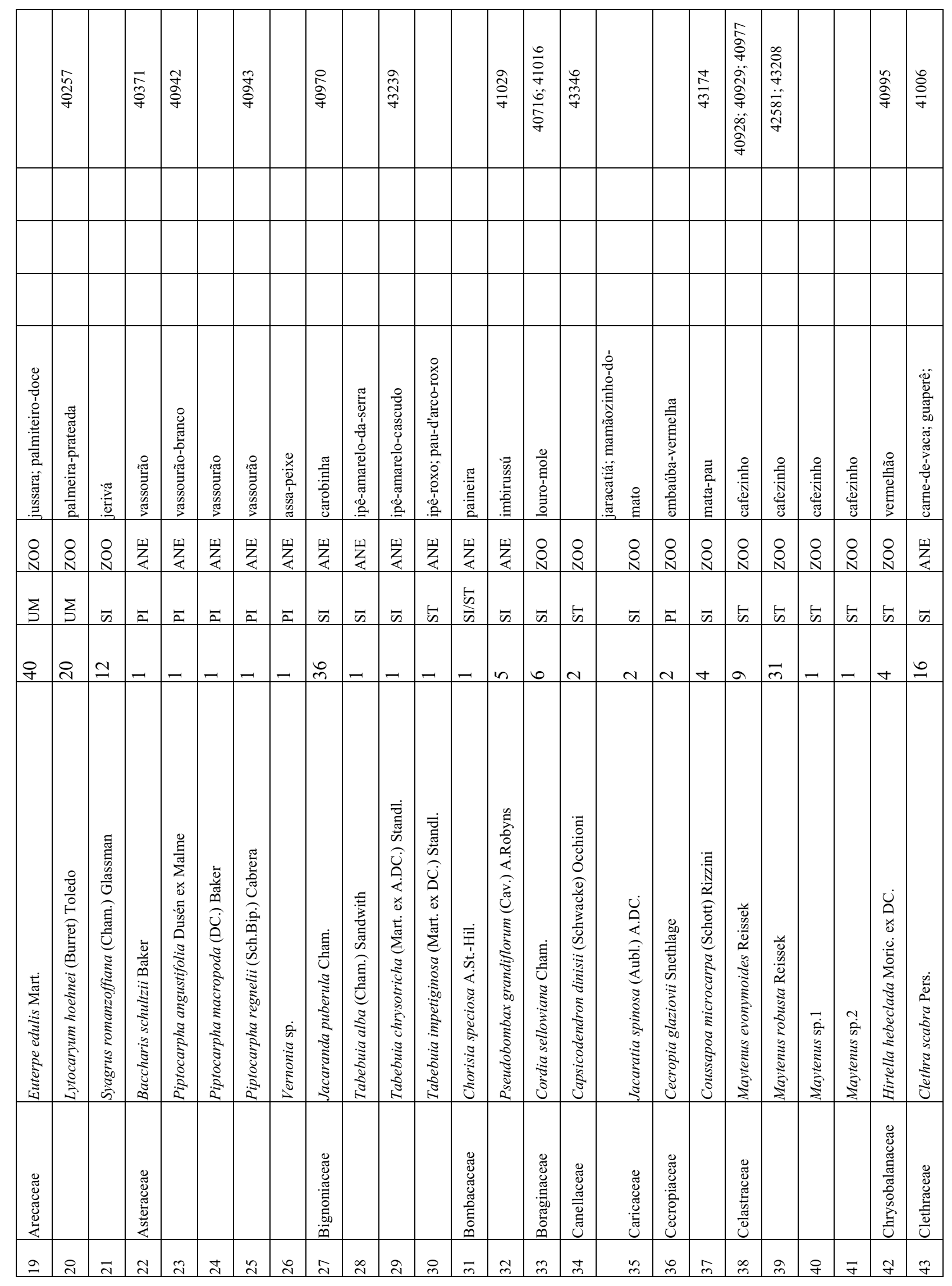




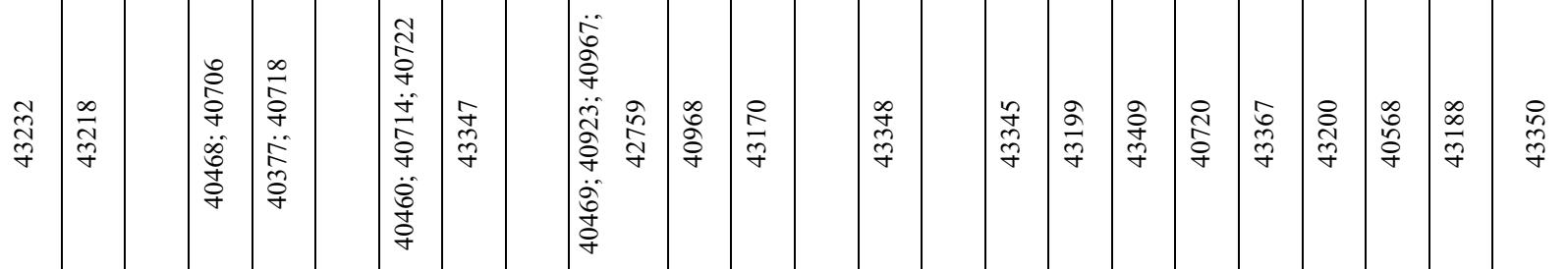

3

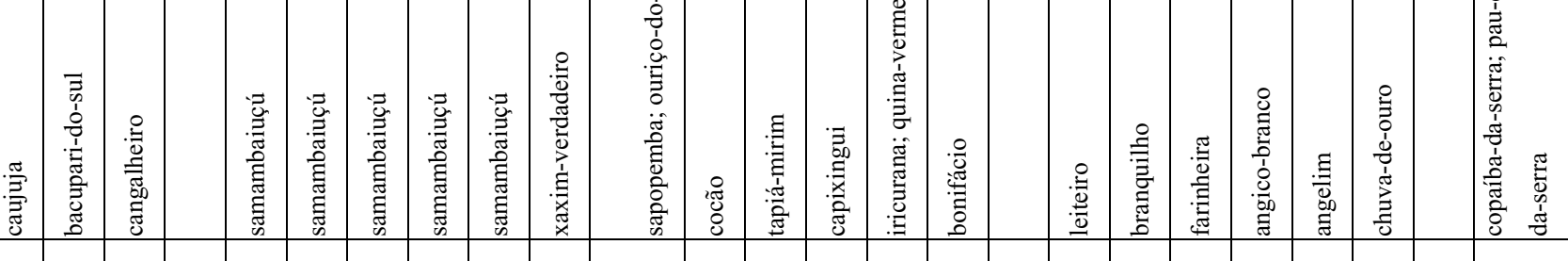

尽

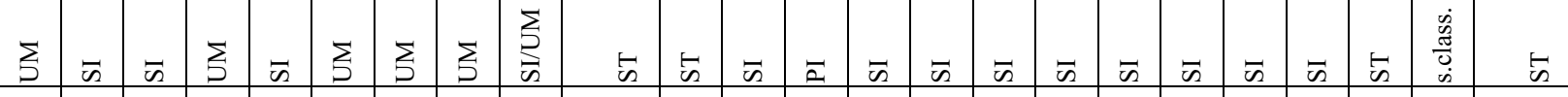

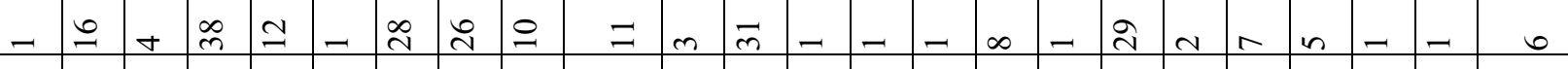

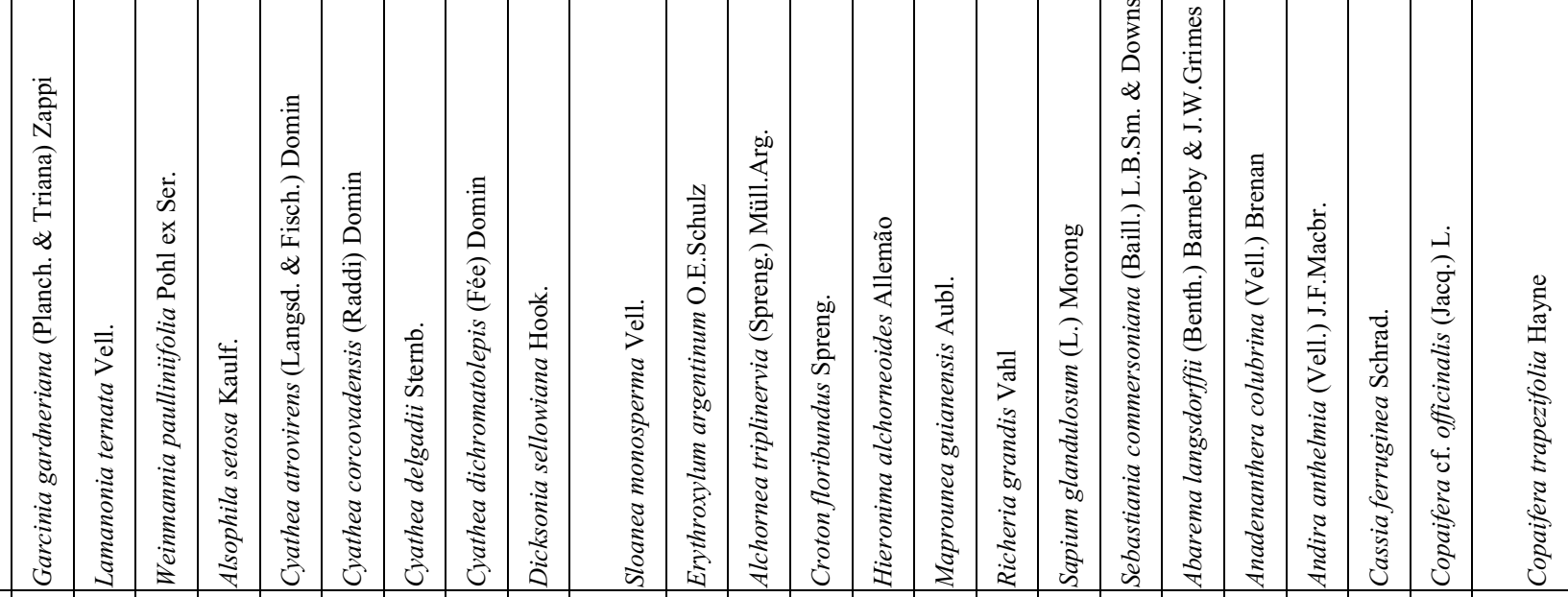

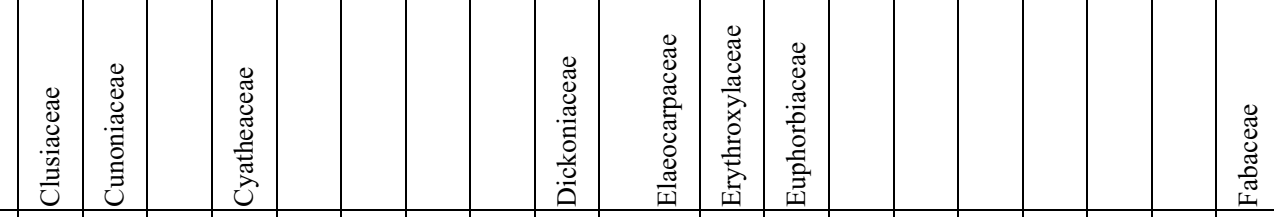

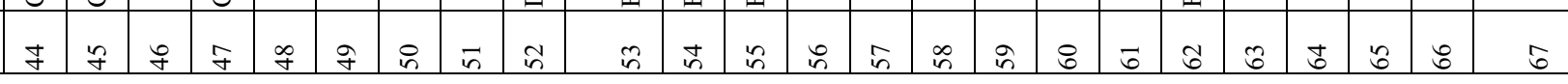




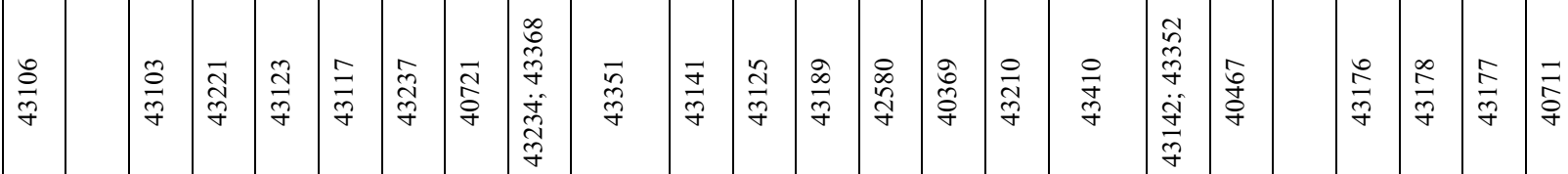

z

ลิ

$\dddot{7}$

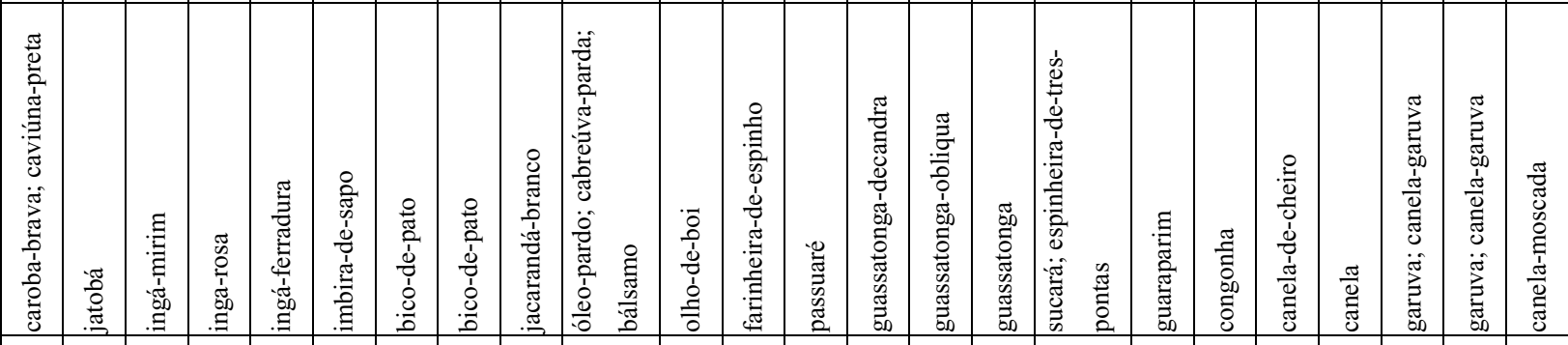

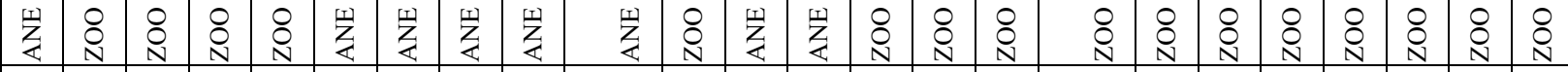

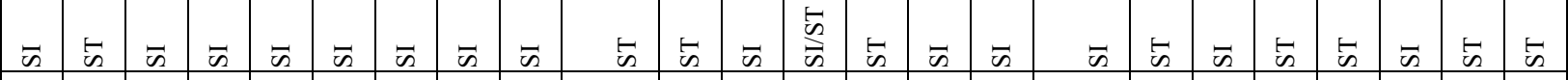

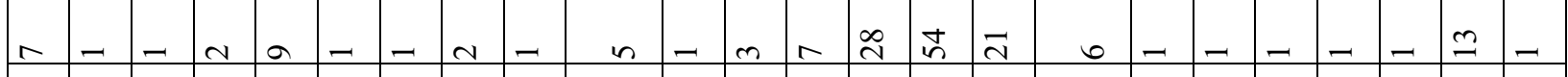

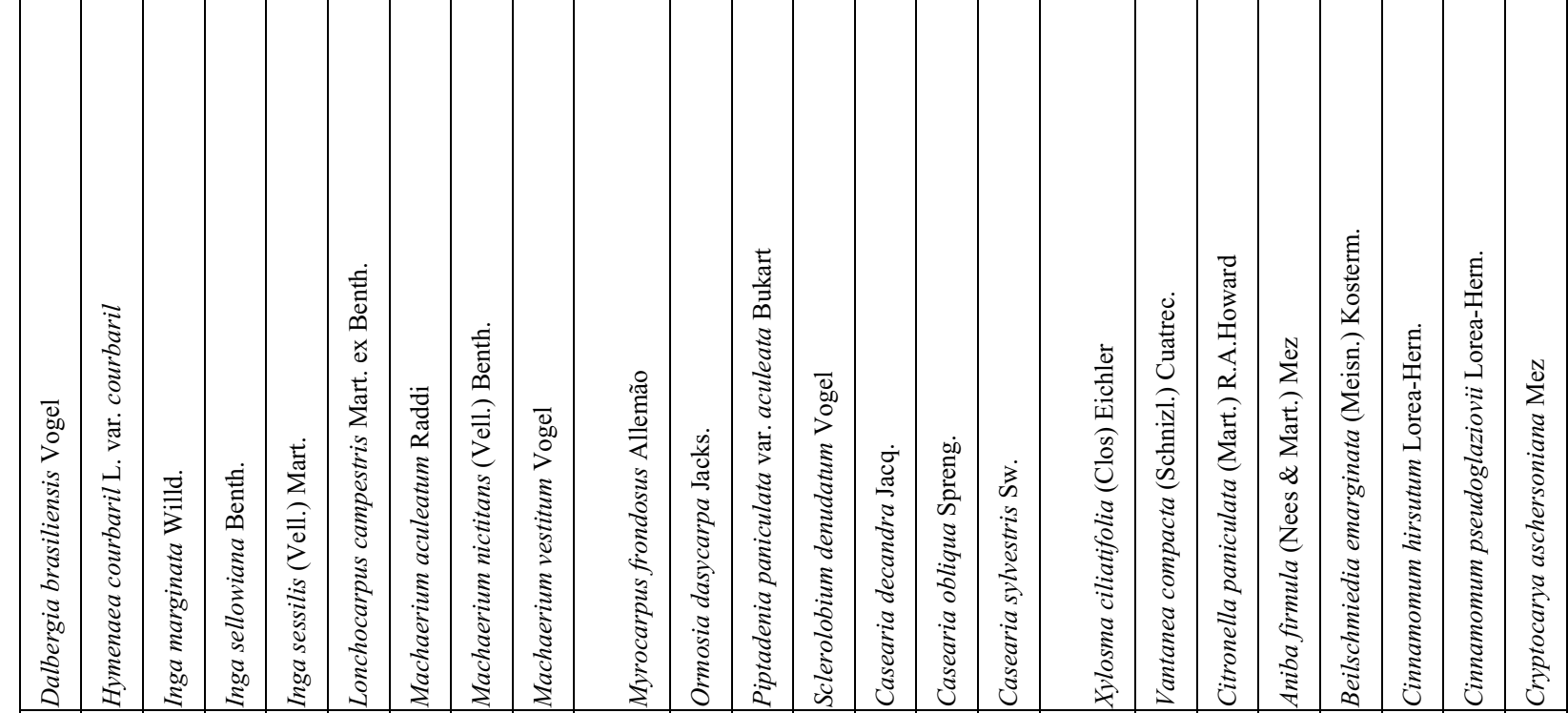

\begin{tabular}{|c|c|c|c|c|c|c|c|c|c|c|c|c|c|c|c|c|c|c|c|c|c|c|}
\hline & & & & & & & & & & & & & 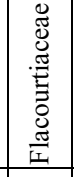 & & & & 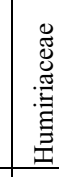 & 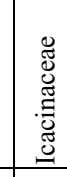 & 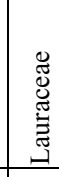 & & & \\
\hline$\infty$ & వి & $\therefore$ & $F$ & 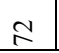 & 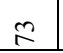 & g & $\approx$ & 2 & $\therefore$ & $\stackrel{\infty}{\sim}$ & iे & $\infty$ & $\vec{\infty}$ & $\infty$ & $\infty$ & $\infty$ & $\infty$ & $\infty$ & $\infty$ & $\mid \infty$ & $\infty$ & 8 \\
\hline
\end{tabular}




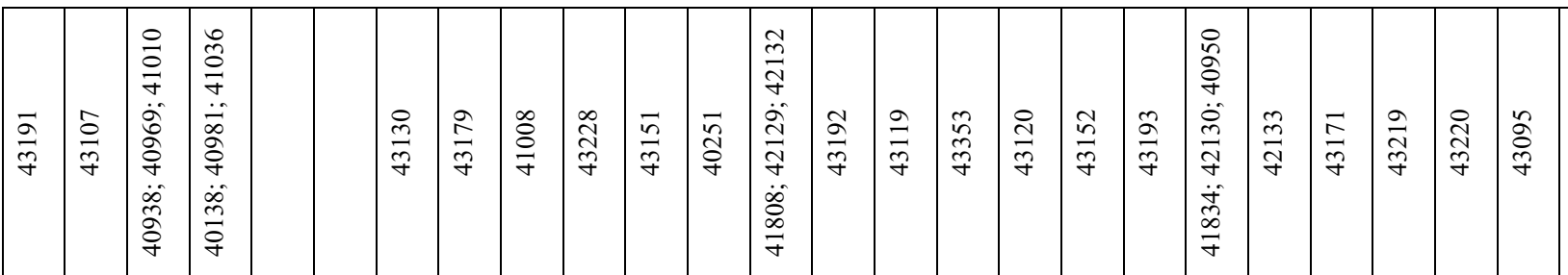

$30 \quad 3 \quad 3$ 39

3

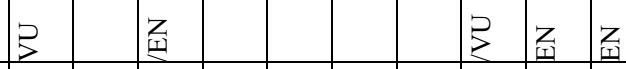
畜

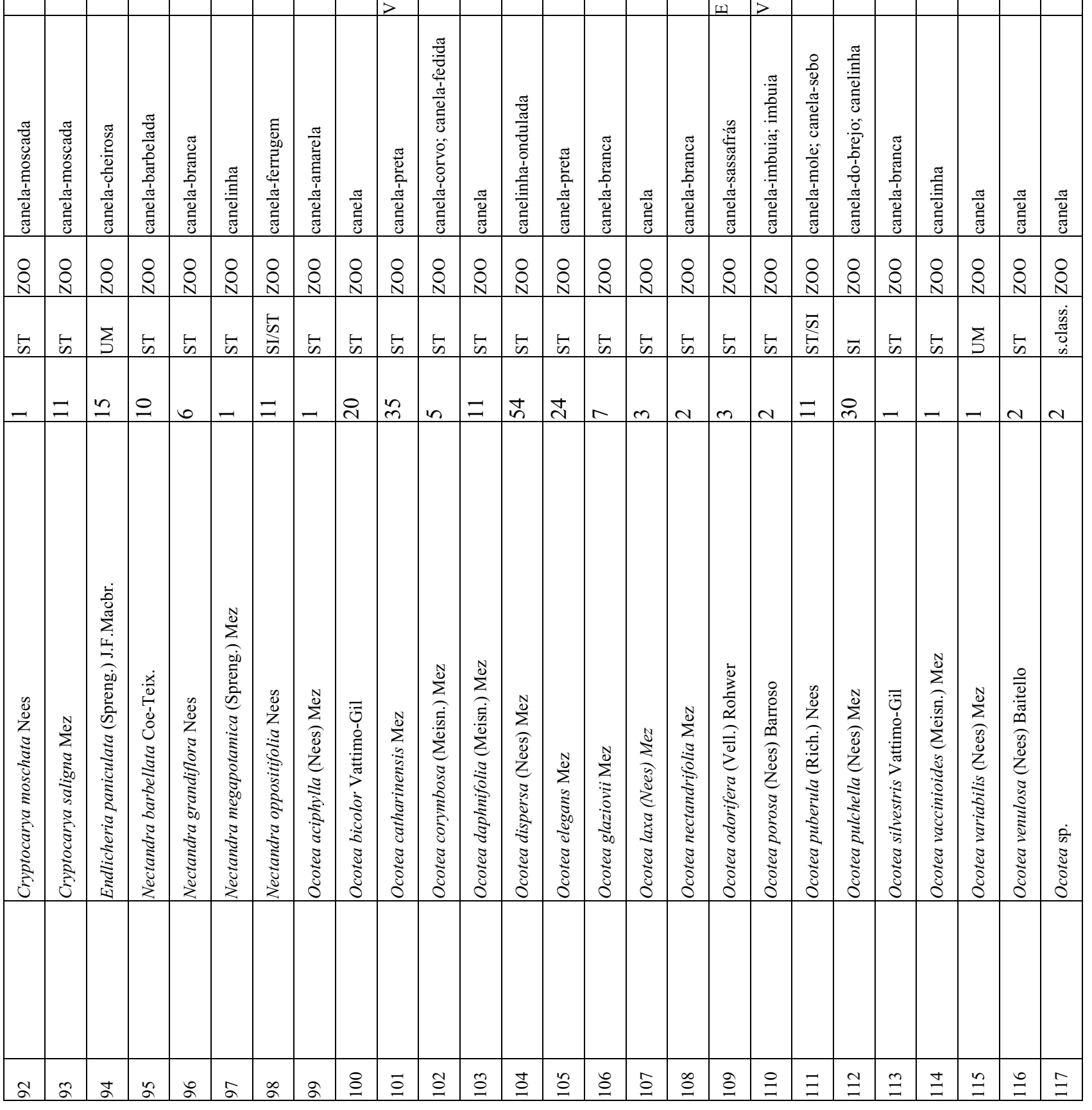




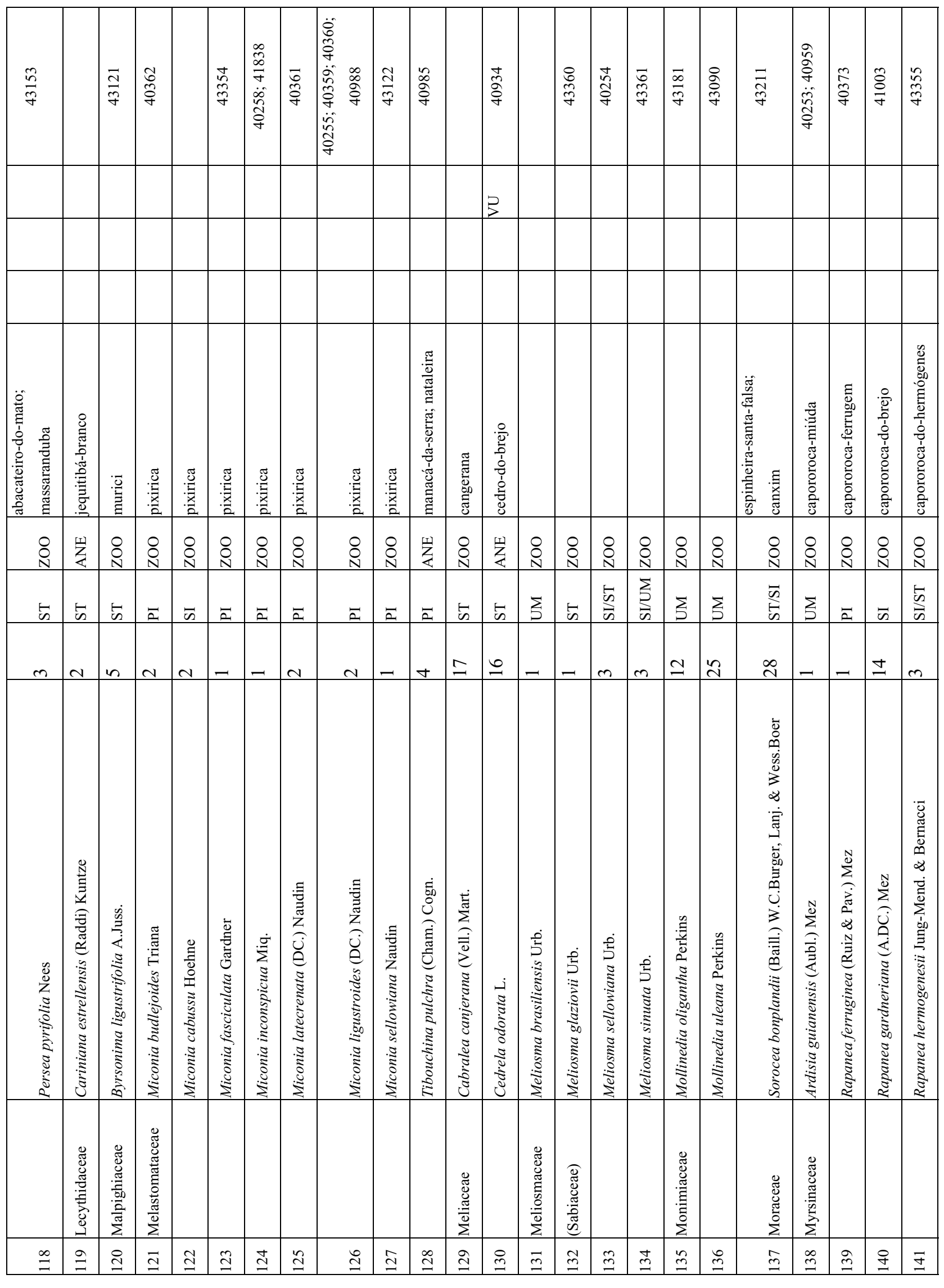




\begin{tabular}{|c|c|c|c|c|c|c|c|c|c|c|c|c|c|c|c|c|c|c|c|c|c|c|}
\hline 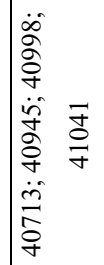 & \begin{tabular}{|l}
$\tilde{N}$ \\
ซे
\end{tabular} & 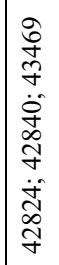 & 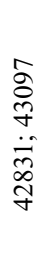 & $\frac{d}{\frac{\Delta}{g}}$ & \begin{tabular}{l}
$\tilde{\approx}$ \\
\multirow{\gamma}{\gamma}{}
\end{tabular} & $\frac{\text { 专 }}{q}$ & $\frac{\overline{8}}{\gamma}$ & $\begin{array}{l}\overrightarrow{\widetilde{N}} \\
\text { ซ్ }\end{array}$ & \begin{tabular}{l} 
శ్ \\
\multirow{\gamma}{*}{}
\end{tabular} & 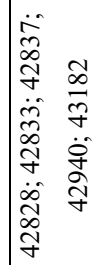 & $\begin{array}{c}\stackrel{\infty}{\not} \\
\frac{\infty}{\sigma}\end{array}$ & 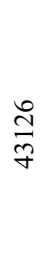 & 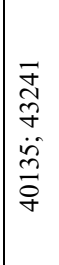 & 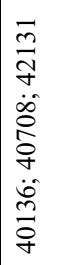 & 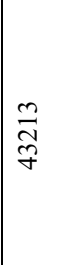 & $\frac{\infty}{\tilde{q}}$ & $\underset{\vec{q}}{\vec{\sigma}}$ & $\frac{t}{\vec{g}}$ & $\begin{array}{l}\text { ఫे } \\
\text { ซे }\end{array}$ & 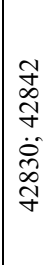 & $\begin{array}{l}\stackrel{J}{\sim} \\
\widetilde{F}\end{array}$ & $\begin{array}{l}\mathcal{J} \\
\widetilde{f}\end{array}$ \\
\hline
\end{tabular}

3

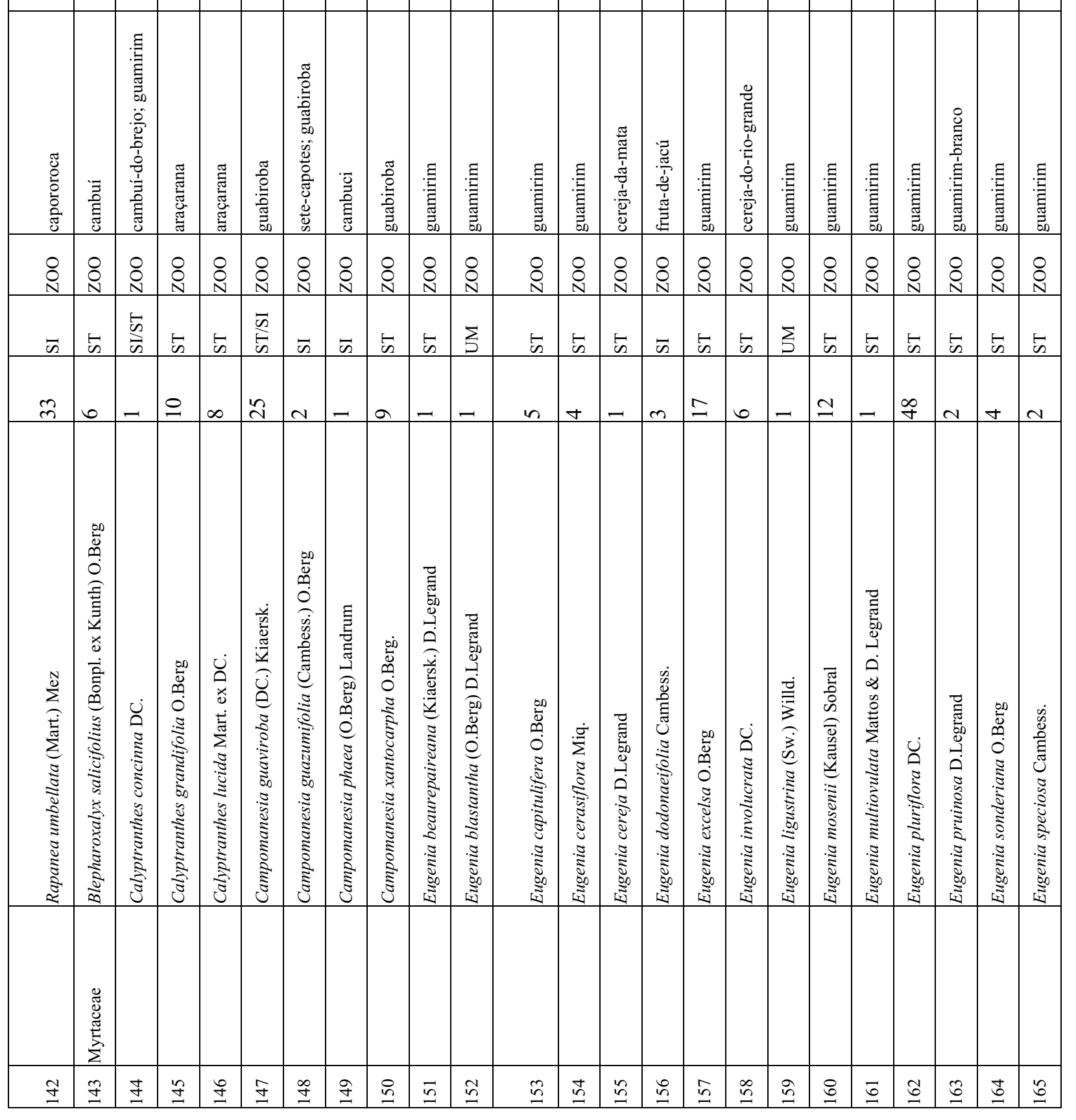




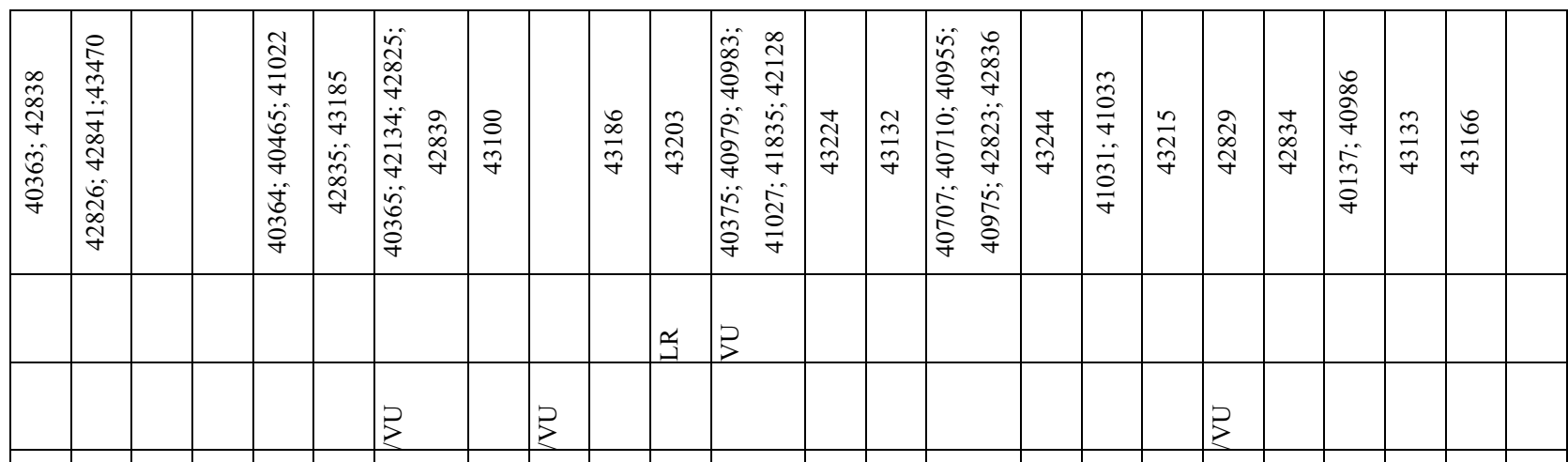

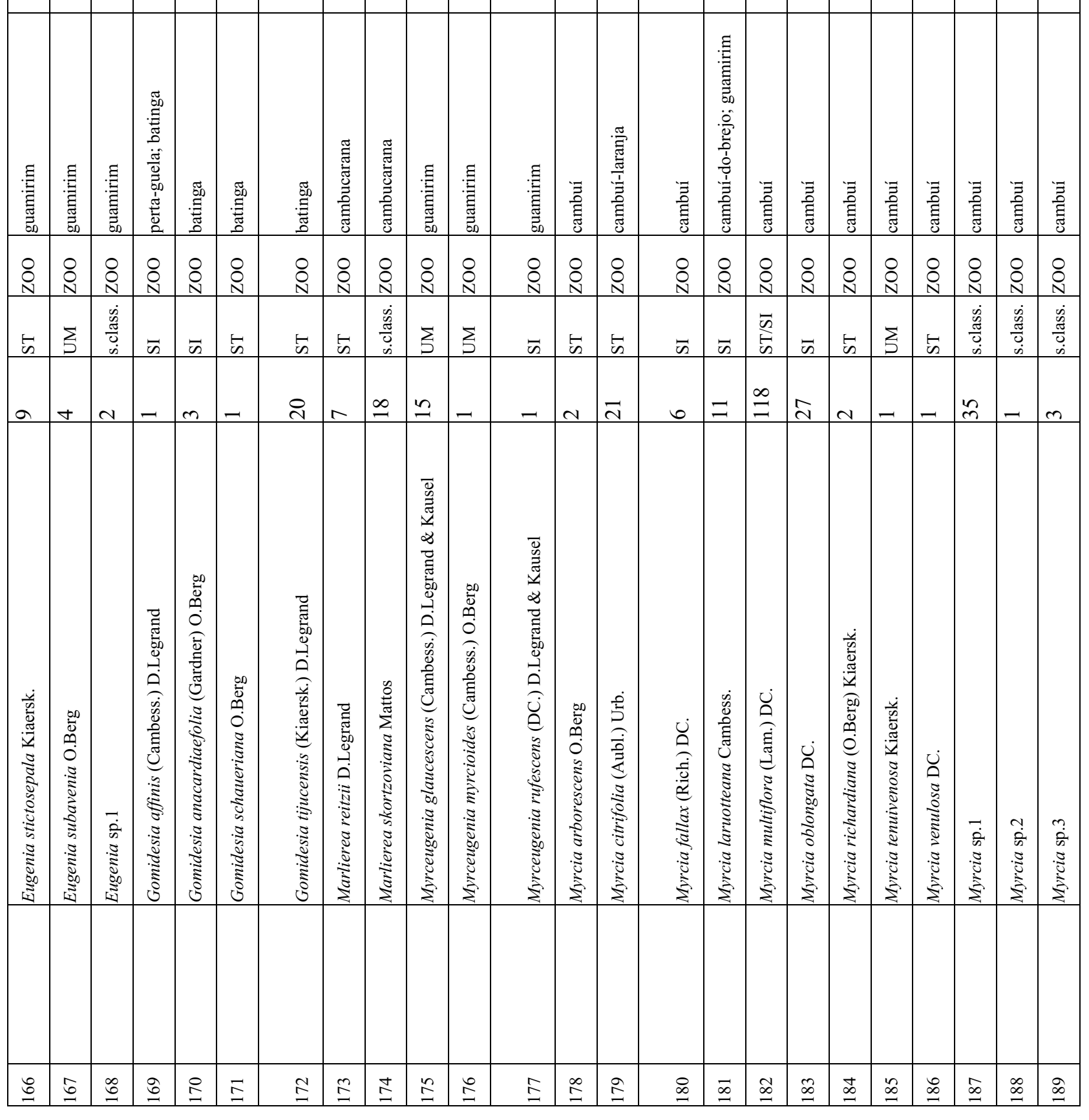




\begin{tabular}{|c|c|c|c|c|c|c|c|c|c|c|c|c|c|c|c|c|c|c|c|}
\hline $\begin{array}{l}\stackrel{\vartheta}{\sigma} \\
\vec{f} \\
\ddot{\partial} \\
\vec{\sigma}\end{array}$ & 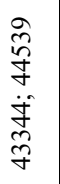 & 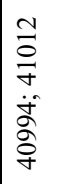 & $\begin{array}{l}\stackrel{0}{\%} \\
\stackrel{\rho}{\sigma}\end{array}$ & 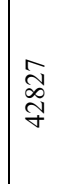 & 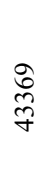 & 各 & ్ָ & $\begin{array}{l}\text { 家 } \\
\tilde{\sigma}\end{array}$ & 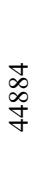 & 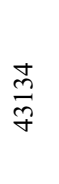 & 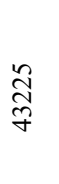 & $\begin{array}{l}\infty \\
\tilde{w} \\
\tilde{f}\end{array}$ & in & $\frac{m}{m}$ & $\frac{⿱ 丷}{m}$ & $\frac{\stackrel{n}{m}}{\ddot{q}}$ & 㐫 & $\begin{array}{l}\stackrel{\widetilde{N}}{\text { f }} \\
\text {. }\end{array}$ & $\begin{array}{l}\overline{\widetilde{\delta}} \\
\vec{\sigma} \\
\ddot{\sigma} \\
\vec{\sigma} \\
\sigma\end{array}$ \\
\hline
\end{tabular}

$\simeq$ $\dddot{7}$

\begin{tabular}{|c|c|c|c|c|c|c|c|c|c|c|c|c|c|c|c|c|c|c|c|c|c|c|c|}
\hline 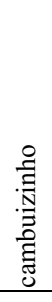 & 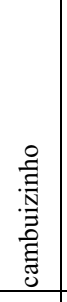 & 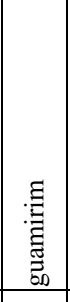 & 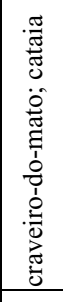 & 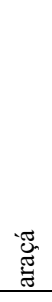 & 总 & & & & 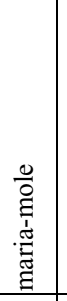 & 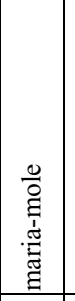 & 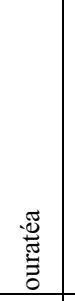 & 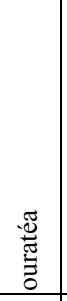 & & & 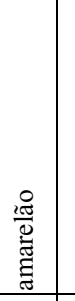 & 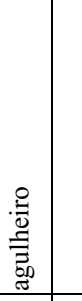 & & 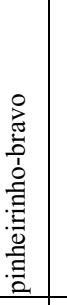 & & 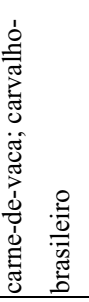 & 急 & 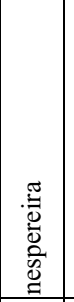 & 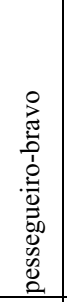 \\
\hline \& & $\stackrel{8}{8}$ & $\stackrel{8}{8}$ & $\stackrel{8}{8}$ & $\stackrel{8}{8}$ & $\stackrel{8}{8}$ & $\stackrel{8}{8}$ & $\stackrel{8}{8}$ & $\stackrel{8}{8}$ & 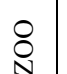 & $\stackrel{8}{8}$ & \& & 8 & $\stackrel{8}{8}$ & 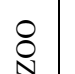 & $\stackrel{8}{8}$ & 崩 & $\stackrel{8}{8}$ & $\stackrel{8}{8}$ & $\stackrel{8}{8}$ & 品 & $\stackrel{8}{8}$ & $\stackrel{8}{8}$ & $\stackrel{8}{8}$ \\
\hline
\end{tabular}

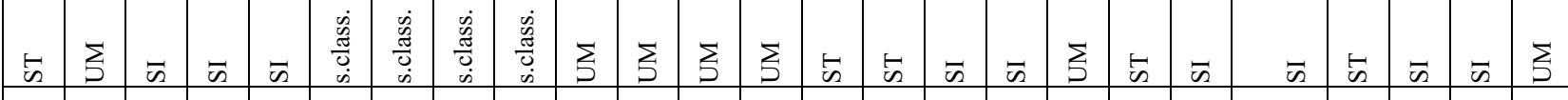

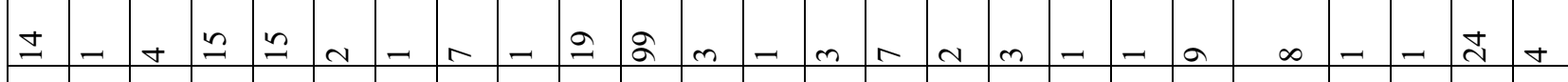

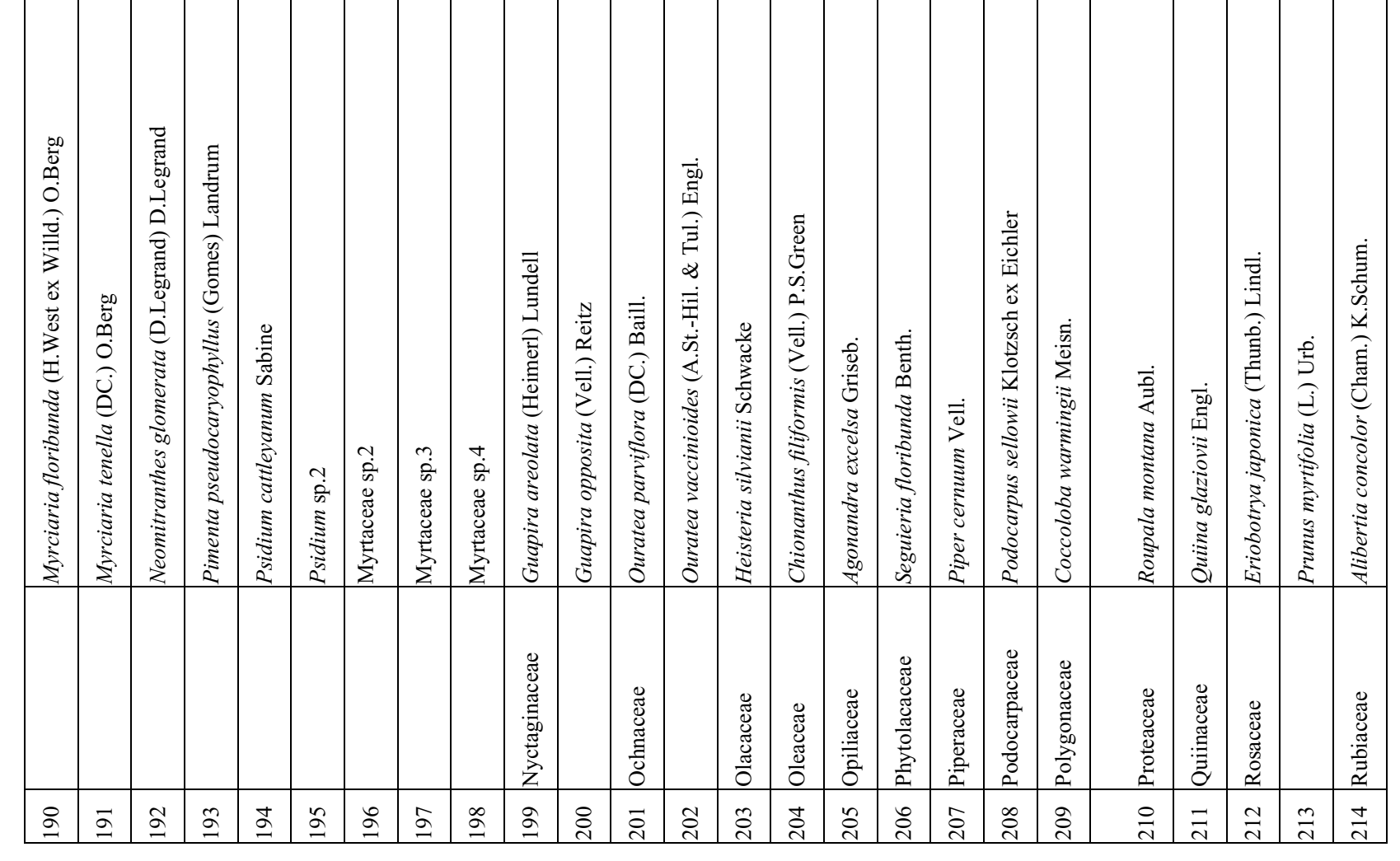




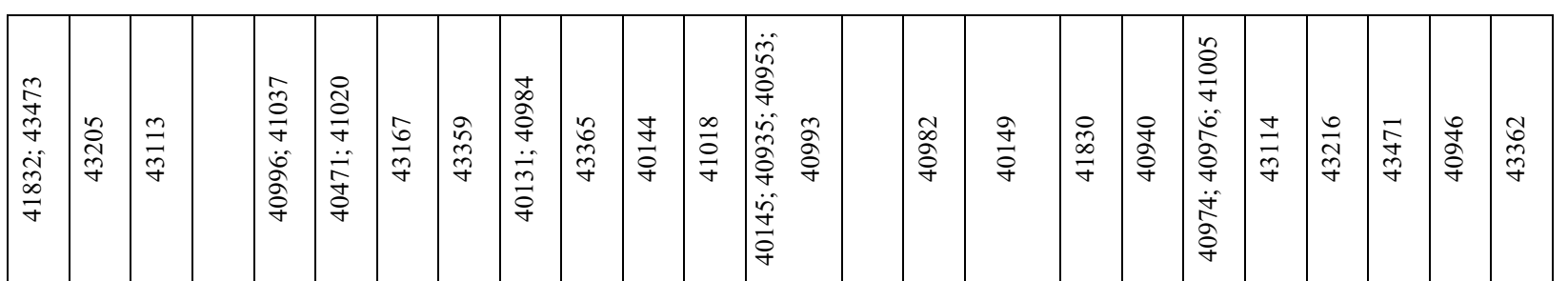

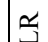

\begin{tabular}{|c|c|c|c|c|c|c|c|c|c|c|c|c|c|c|c|c|c|c|c|c|c|c|}
\hline & 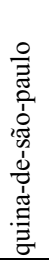 & 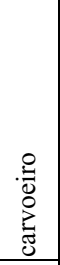 & 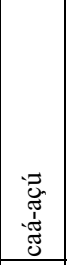 & & & 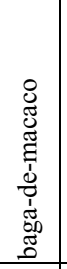 & & & & & 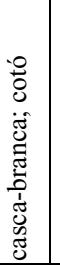 & 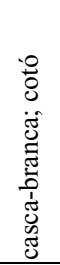 & 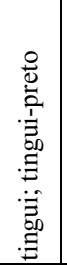 & 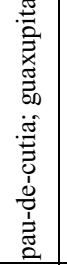 & 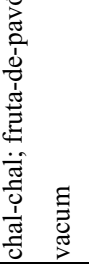 & 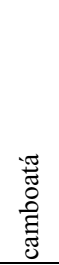 & 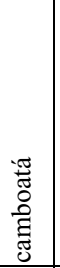 & 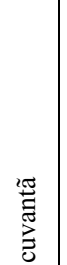 & 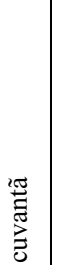 & 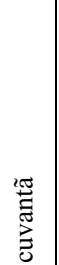 & 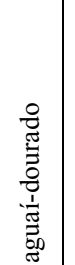 & 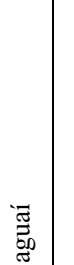 \\
\hline & $\frac{11}{z}$ & 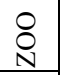 & 岁 & $\underset{N}{\stackrel{N}{2}}$ & $\underset{\sim}{\stackrel{ }{8}}$ & $\underset{\mathrm{N}}{\stackrel{8}{0}}$ & 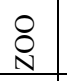 & $\underset{N}{\stackrel{ }{*}}$ & 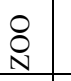 & $\underset{\sim}{8}$ & \& & $\underset{\mathrm{N}}{\stackrel{8}{ }}$ & 罗 & $\stackrel{5}{5}$ & $\underset{N}{\stackrel{8}{N}}$ & $\underset{N}{\stackrel{8}{\circ}}$ & $\underset{N}{\stackrel{ }{8}}$ & $\underset{\mathrm{N}}{\stackrel{8}{0}}$ & $\underset{N}{\stackrel{8}{\circ}}$ & $\underset{\mathrm{N}}{\stackrel{\mathrm{O}}{ }}$ & $\underset{\mathrm{N}}{\stackrel{8}{2}}$ & ஓ \\
\hline
\end{tabular}

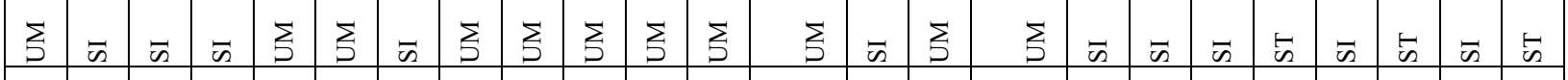

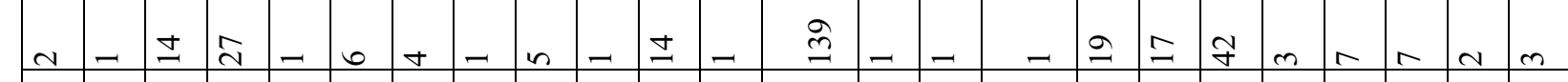

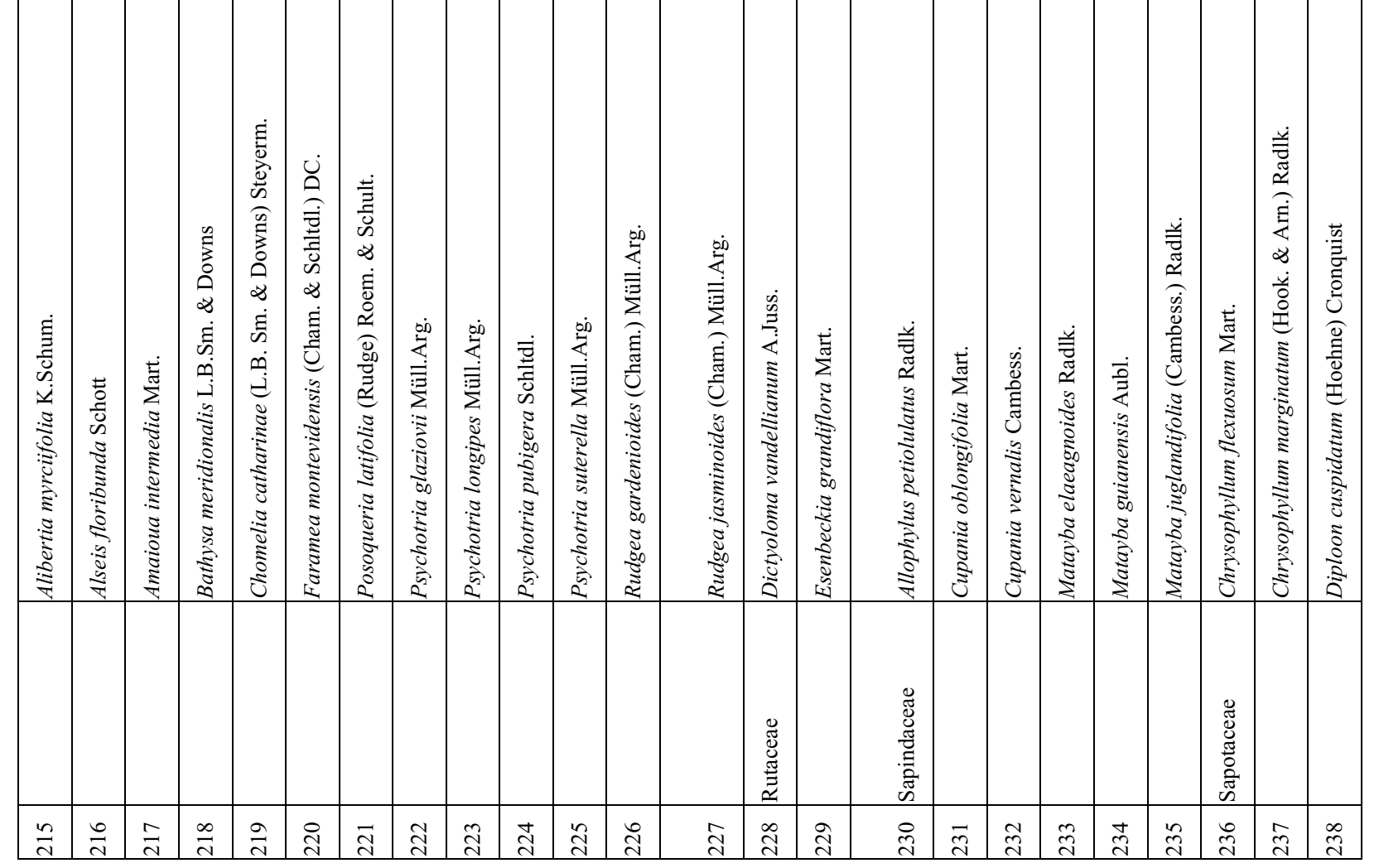




\begin{tabular}{|c|c|c|c|c|c|c|c|c|c|c|c|c|c|c|c|c|c|c|c|}
\hline 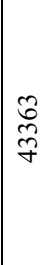 & 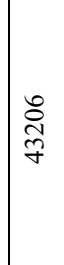 & $\begin{array}{l}\hat{\widetilde{N}} \\
\tilde{\gamma}\end{array}$ & $\begin{array}{l}\stackrel{2}{0} \\
\hat{\sigma} \\
\dot{q} \\
\ddot{+} \\
\stackrel{+}{+}\end{array}$ & 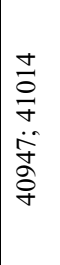 & 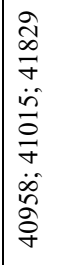 & 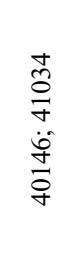 & 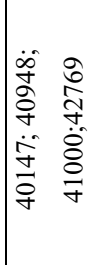 & 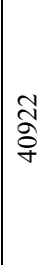 & 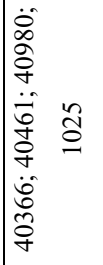 & $\frac{m}{\sigma}$ & 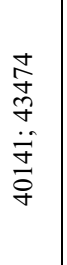 & $\stackrel{\substack{++}}{+}$ & $\begin{array}{l}\stackrel{8}{\circ} \\
\stackrel{9}{\sigma}\end{array}$ & 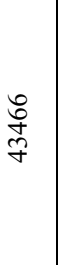 & 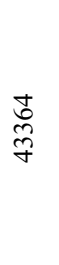 & $\begin{array}{l}\text { ثे } \\
\widetilde{\gamma}\end{array}$ & $\frac{\tilde{n}}{\tilde{q}}$ & 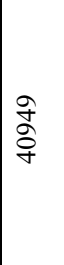 & 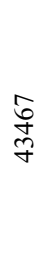 \\
\hline & 3 & & & & $\dddot{\exists}$ & $\mathfrak{\exists}$ & & & & & & & & & & & & & \\
\hline
\end{tabular}

\begin{tabular}{|c|c|c|c|c|c|c|c|c|c|c|c|c|c|c|c|c|c|c|c|c|c|}
\hline & & & & & & & & & & & & & & & & & & & & & \\
\hline 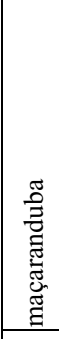 & 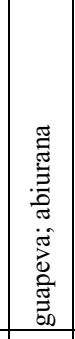 & 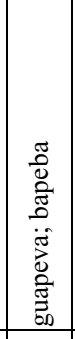 & & 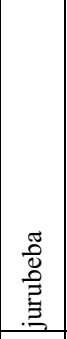 & 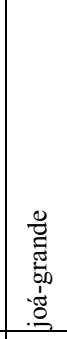 & 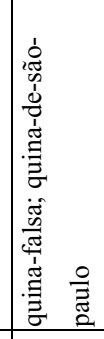 & & 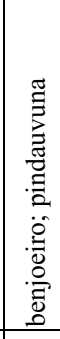 & 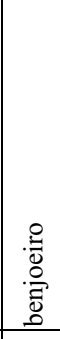 & 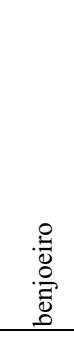 & & & & & 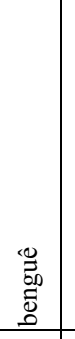 & 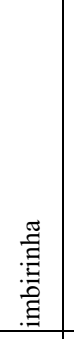 & 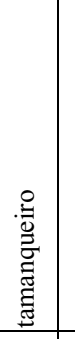 & 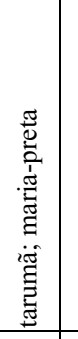 & 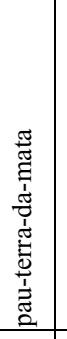 & 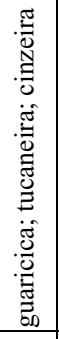 & 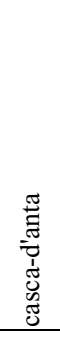 \\
\hline \& & $\stackrel{8}{8}$ & $\underset{N}{\stackrel{8}{N}}$ & $\underset{ }{\stackrel{\circ}{ }}$ & $\stackrel{8}{\stackrel{8}{N}}$ & $\underset{\mathrm{N}}{\stackrel{8}{ }}$ & \& & \& & 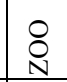 & $\underset{N}{\stackrel{8}{0}}$ & $\stackrel{8}{\circ}$ & $\underset{N}{\stackrel{8}{\circ}}$ & $\underset{N}{\stackrel{ }{8}}$ & $\underset{N}{\stackrel{8}{0}}$ & 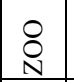 & $\underset{N}{\stackrel{\circ}{\circ}}$ & $\stackrel{8}{\circ}$ & $\underset{4}{5}$ & \& & 岁 & 㞱 & 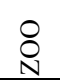 \\
\hline
\end{tabular}

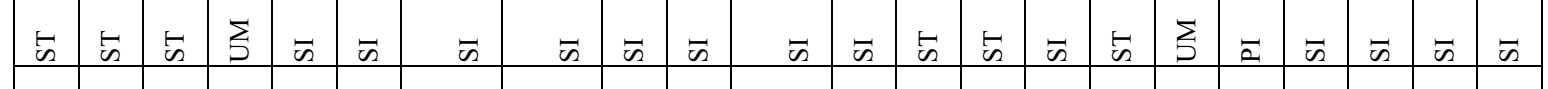

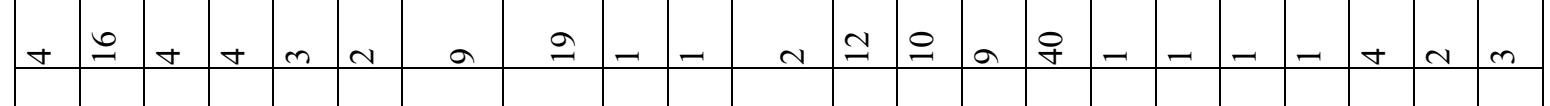

\begin{tabular}{|c|c|c|c|c|c|c|c|c|c|c|c|c|c|c|c|c|c|c|c|c|c|}
\hline 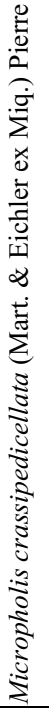 & 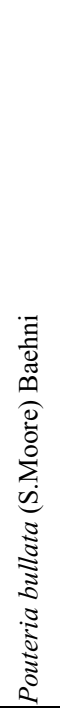 & 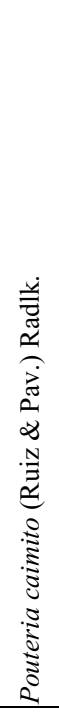 & 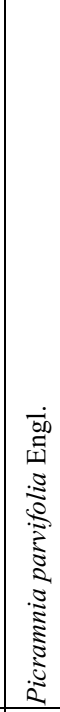 & 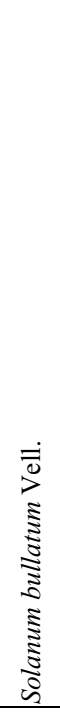 & 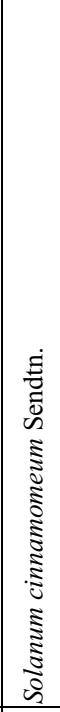 & 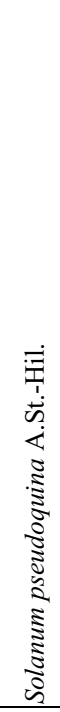 & 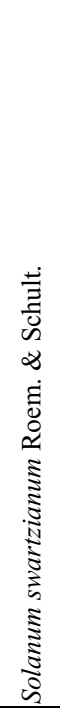 & 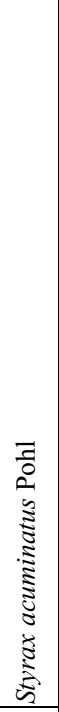 & 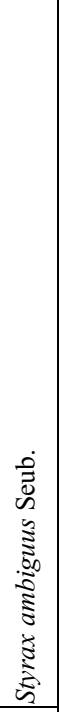 & 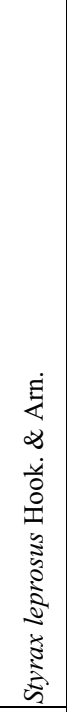 & 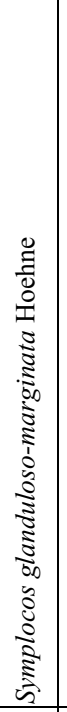 & 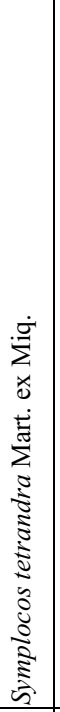 & 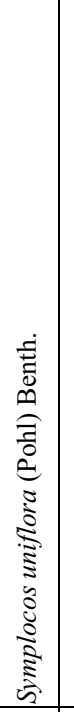 & 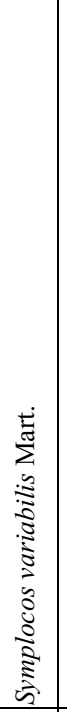 & 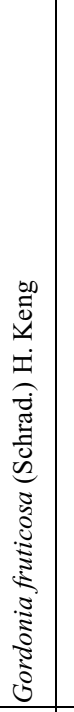 & 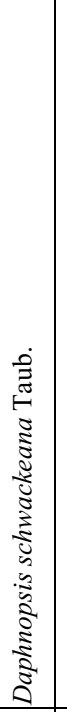 & 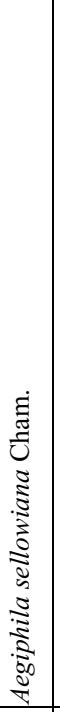 & 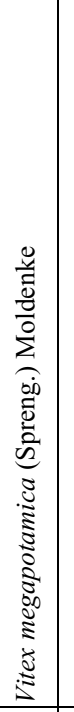 & 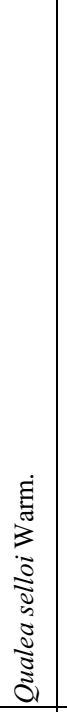 & 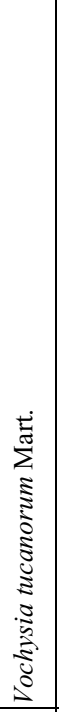 & 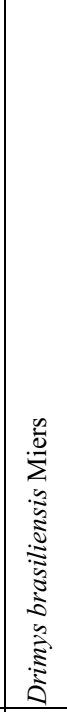 \\
\hline & & & 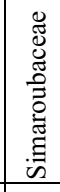 & 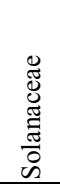 & & & & 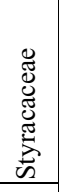 & & & 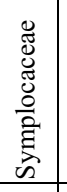 & & & & $\begin{array}{l}\mathscr{\Xi} \\
\mathbb{\Xi} \\
\Xi \\
\Xi \\
\end{array}$ & 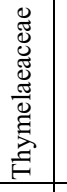 & 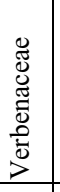 & & 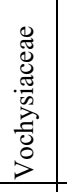 & & 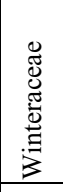 \\
\hline సે & 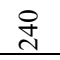 & $\vec{J}$ & $\stackrel{\mathfrak{I}}{\sim}$ & $\stackrel{\stackrel{\sim}{\sim}}{\sim}$ & $\underset{\sim}{\stackrel{J}{*}}$ & $\stackrel{\text { q }}{d}$ & $\stackrel{J}{d}$ & $\underset{\sim}{\stackrel{9}{J}}$ & $\stackrel{\infty}{\sim}$ & d্ & in & $\overline{\text { ते }}$ & $\tilde{్ ָ}$ & $\tilde{\sim}$ & 点 & nิ & $\begin{array}{l}0 \\
\end{array}$ & in & 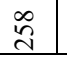 & हे & $\stackrel{\sim}{\circ}$ \\
\hline
\end{tabular}


Tabela 2. Número de indivíduos, espécies, e famílias, e valores de diversidade (Shannon-Weaver, H’) e equabilidade para cada área amostrada na Reserva Florestal do Morro Grande, Cotia, SP.

Table 2. Number of individuals, species and families, and diversity (Shannon-Weaver, H') and evenness (J) values for each study site in the Morro Grande Forest Reserve, Cotia, SP.

\begin{tabular}{|c|c|c|c|c|c|}
\hline Área & Indivíduos & Espécies & Famílias & $\begin{array}{r}\text { Diversidade } \\
\left(\mathrm{H}^{\prime}\right)\end{array}$ & $\begin{array}{r}\text { Equabilidade } \\
(\mathrm{J})\end{array}$ \\
\hline A & 400 & 74 & 35 & 3,558 & 0,827 \\
\hline B & 400 & 92 & 32 & 3,885 & 0,859 \\
\hline $\mathbf{C}$ & 400 & 93 & 41 & 3,979 & 0,878 \\
\hline Q - Quilombo & 400 & 103 & 39 & 4,081 & 0,880 \\
\hline G - Grilos & 400 & 108 & 44 & 4,151 & 0,887 \\
\hline T - Torres & 400 & 109 & 40 & 4,258 & 0,906 \\
\hline Florestas secundárias $(A+B+C)$ & 1200 & 157 & 49 & 4,245 & 0,839 \\
\hline Florestas maduras $(\mathbf{Q}+\mathbf{G}+\mathbf{T})$ & 1200 & 179 & 56 & 4,536 & 0,875 \\
\hline TOTAL & 2400 & 260 & 64 & 4,754 & 0,855 \\
\hline
\end{tabular}

http://www.biotaneotropica.org.br 
Tabela 3: Número e percentagem de espécies por síndrome de dispersão amostrados nas seis grandes áreas de amostragem na Reserva Florestal do Morro Grande.

Table 3. Number and percentage of species per dispersion class in six study sites in the Morro Grande Forest Reserve.

\begin{tabular}{lcrrrrrr}
\hline Área & \multicolumn{2}{r}{ Anemocóricas } & \multicolumn{2}{r}{ Barocórica } & Zoocóricas & Total \\
\hline & & $\mathbf{( \% )}$ & & $\mathbf{( \% )}$ & & $\mathbf{( \% )}$ & \\
\hline $\mathbf{A}$ & 11 & $(15)$ & 1 & $(1)$ & 62 & $(84)$ & 74 \\
$\mathbf{B}$ & 13 & $(14)$ & 3 & $(3)$ & 76 & $(83)$ & 92 \\
$\mathbf{C}$ & 15 & $(16)$ & 1 & $(1)$ & 77 & $(83)$ & 93 \\
$\mathbf{Q}$ & 10 & $(10)$ & 1 & $(1)$ & 92 & $(89)$ & 103 \\
$\mathbf{G}$ & 17 & $(16)$ & 3 & $(3)$ & 88 & $(81)$ & 108 \\
$\mathbf{T}$ & 20 & $(19)$ & 6 & $(4)$ & 84 & $(77)$ & 109 \\
\hline
\end{tabular}

http://www.biotaneotropica.org.br 


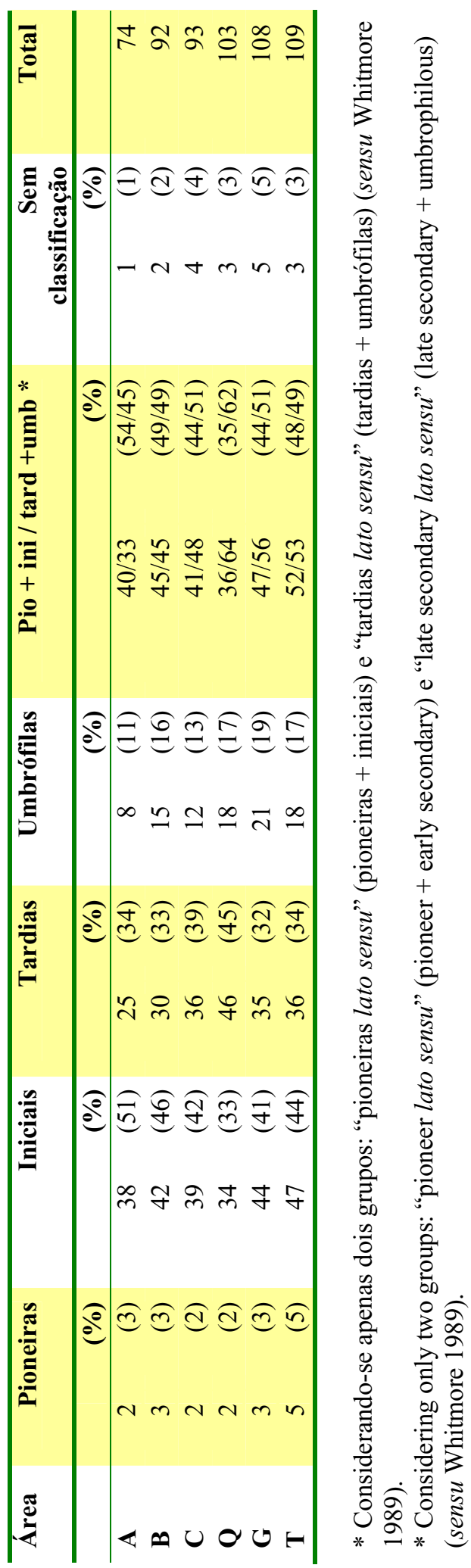


Informacão remanescente (\%)

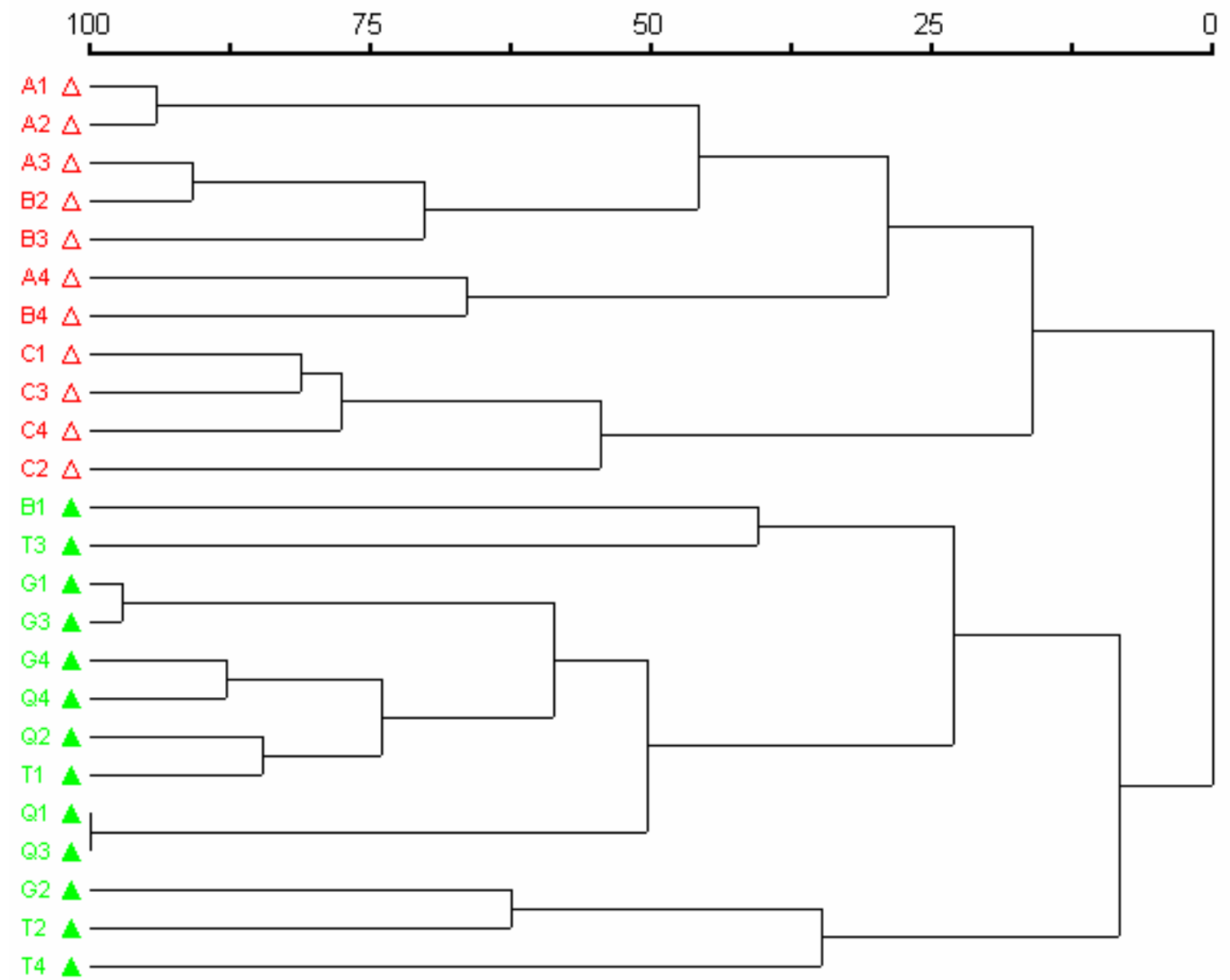

Figura 1. Agrupamento dos 24 blocos amostrados na Reserva Florestal do Morro Grande (Cotia, SP) em áreas secundárias (A, B e C) e maduras (Q, G e T), utilizando a distância de Sørensen (Bray-Curtis) e a média entre grupos (UPGMA). A informação remanescente expressa a quantidade de informação responsável pela ligação entre os grupos formados (Wishart 1969).

Figure 1. Cluster of the 24 plots used to sample the Morro Grande Forest Reserve (Cotia, SP) in medium to old secondary forests (A, B and C) and mature forests (Q, G and $\mathrm{T})$, using the Sørensen (Bray-Curtis) distance and group average (UPGMA). The percentage of information remaining state the quantity of information responsible for the link among groups (Wishart 1969). 


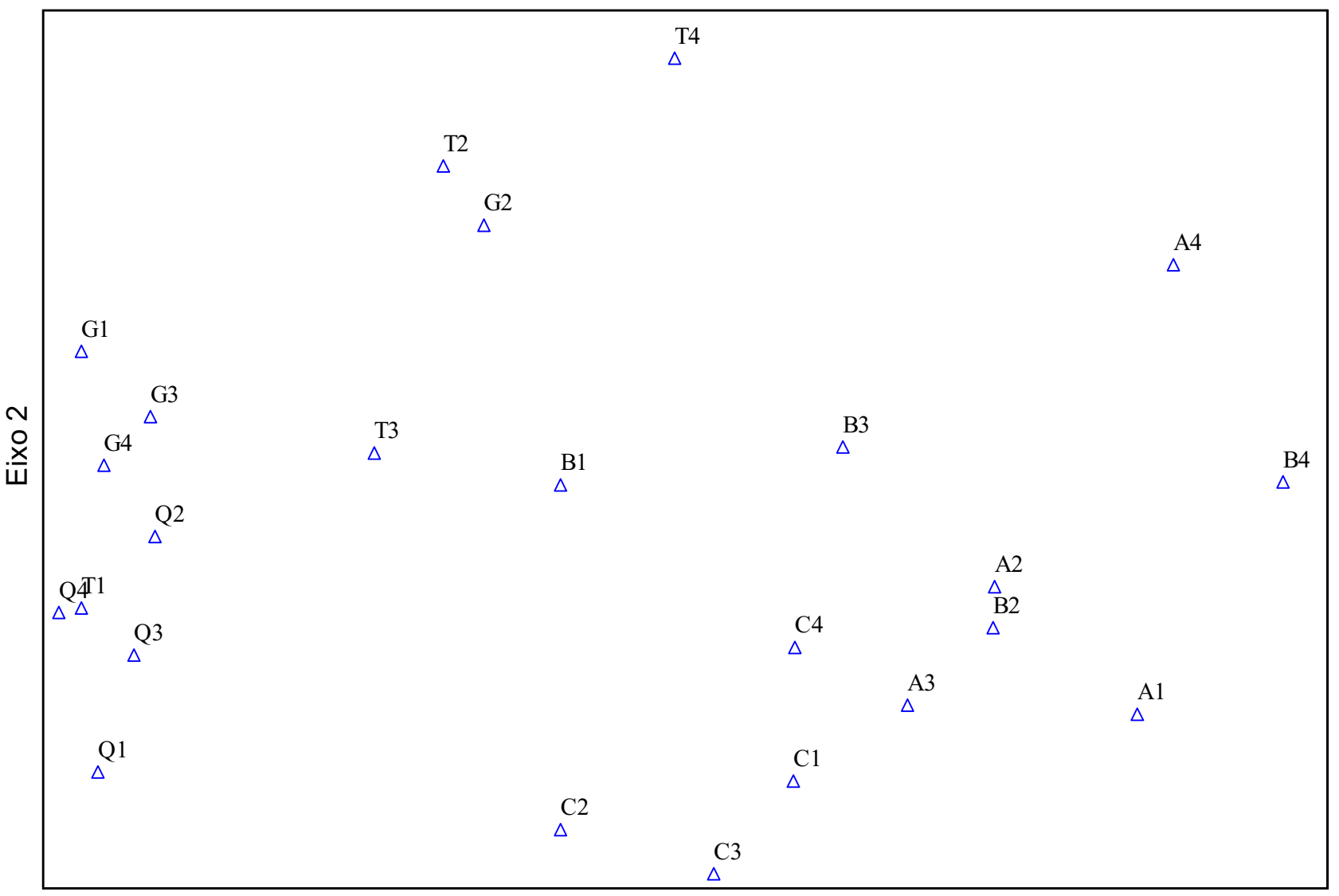

Eixo 1

Figura 2. Distribuição dos 24 sítios analisados na Reserva Florestal do Morro Grande (Cotia, SP) em áreas secundárias (A, B e C) e maduras $(Q, G$ e $T$ ) segundo os dois primeiros eixos de uma Análise de Correspondência Destendenciada (DCA), com opção de rescalonamento dos eixos e minimização do peso das espécies raras.

Figure 2. Distribution of the 24 plots used to sample the Morro Grande Forest Reserve (Cotia, SP) in medium to old secondary forests (A, B and $\mathrm{C})$ and mature forests (Q, G and $\mathrm{T}$ ) according to the two first axis in an Detrended Correspondence Analysis (DCA), using rescaling threshold and downweight rare species options. 